The Journal of Toxicological Sciences Vol. 15, Supplement II, 11-41, 1990

Mofezolac (N-22) のラット経口投与による

3 力月間亜急性毒性試験および 1 力月間回復試験

\author{
新保幸太郎, 竹内 雅也, 岡崎 修三, 木口 雅夫, 橋本由佳里, \\ 青木由加利, 桑田 雅彦*, 山下 和正* \\ 株式会社化合物安全性研究所 \\ *大鵬薬品工業株式会社 研究開発本部 安全性研究所
}

\title{
THREE-MONTH ORAL SUBACUTE TOXICITY STUDY OF MOFEZOLAC (N-22) IN RATS
}

\author{
Kotaro SHIMPO, Masaya TAKEUCHI, Shūzō OKAZAKI, Masao KIGUCHI, \\ Yukari HASHIMOTO, Yukari AOKI, Masahiko KUWATA* \\ and Kazumasa YAMASHITA* \\ Safety Research Institute for Chemical Compounds Co., Ltd., \\ 2-20, Nishi 11-chome, Kita 30-joh, Kita-ku, Sapporo 001, Japan \\ ${ }^{*}$ Drug Safety Laboratory, Taiho Pharmaceutical Co., Ltd., \\ 224-2 Ebisuno, Hiraishi, Kawauchi-cho, Tokushima 771-01, Japan
}

Accepted April 20, 1990

\begin{abstract}
A three-month oral subacute toxicity study of mofezolac $(\mathrm{N}-22)$, a non-steroidal anti-inflammatory agent, was performed using dose levels of 6,20 , 60 and $200 \mathrm{mg} / \mathrm{kg}$ in rats, and recovery was also assessed one month after withdrawal.

1. Toxic signs caused by $\mathrm{N}-22$ administration, observed only in the $200 \mathrm{mg} / \mathrm{kg}$ group, were as follows : soiling around the mouth and/or nose, piloerection, anemia, diarrhea, emaciation and decreased spontaneous locomotor activity.

Nine males and thirteen females in the $200 \mathrm{mg} / \mathrm{kg}$ group excreted bloody diarrhea and died of general exhaustion between weeks four and thirteen of study.

2. In the $200 \mathrm{mg} / \mathrm{kg}$ group, decrease in food consumption and suppression of body weight gain were noted in males from about week four and in females from about week six after initiation of administration, and increase in water consumption was noted in males from about week seven.
\end{abstract}

連絡先：画771-01 *徳島市川内町平石字夷野224-2

大鵬薬品工業株式会社 研究開発本部 安全性研究所 山下 和正 


\section{K. SHIMPO et al.}

3. Urinary examination revealed a decline in urinary $\mathrm{pH}$ in males of the 20 $\mathrm{mg} / \mathrm{kg}$ and above groups and elevation of urobilinogen levels in males of the 60 and $200 \mathrm{mg} / \mathrm{kg}$ groups.

4. Hematological examination showed decreases in erythrocyte count (RBC), hematocrit value $(\mathrm{Ht})$ and hemoglobin concentration $(\mathrm{Hb})$ and increase in reticulocyte rate in both sexes of the $200 \mathrm{mg} / \mathrm{kg}$ group and an increase in neutrophil rate in males of the $200 \mathrm{mg} / \mathrm{kg}$ group.

5. Biochemical examination demonstrated a decrease in chloride $\left(\mathrm{Cl}^{-}\right)$in males receiving the $20 \mathrm{mg} / \mathrm{kg}$ or above doses and a decrease in calcium $\left(\mathrm{Ca}^{++}\right)$in males of the 60 and $200 \mathrm{mg} / \mathrm{kg}$ groups. Moreover, there were decreases in cholinesterase (ChE) activity, total protein (TP) and albumin (Alb) values, as well as increases in blood urea nitrogen (BUN), uric acid (UA) and potassium $\left(\mathrm{K}^{+}\right)$in both sexes of the $200 \mathrm{mg} / \mathrm{kg}$ group, along with elevations in GOT and lactate dehydrogenase ( $\mathrm{LDH}$ ) activities in females of the $200 \mathrm{mg} / \mathrm{kg}$ group.

6. The absolute and/or relative organ weights for liver, kidneys, spleen and adrenals were increased in the $200 \mathrm{mg} / \mathrm{kg}$ group.

7. On pathological examination, perforating ulceration in the jejunum and ileum, turbid ascites, adhesion and inflammatory changes in capsules of the abdominal organs, splenomegaly, mesenteric lymph node hyperplasia and inflammatory changes in the thoracic cavity were observed in dead animals of the $200 \mathrm{mg} / \mathrm{kg}$ group. Similar pathological changes were observed in a few survival cases of the 200 $\mathrm{mg} / \mathrm{kg}$ group.

8. After a one month recovery period, the above-mentioned changes had mostly recovered, indicating that they were reversible.

9. These results suggested no-effect dose levels of $\mathrm{N}-22$ in rats to be $6 \mathrm{mg} / \mathrm{kg}$ for males and $60 \mathrm{mg} / \mathrm{kg}$ for females, and the toxic dose level to be $200 \mathrm{mg} / \mathrm{kg}$ for both sexes.

Key words : Mofezolac, N-22, analgesic and anti-inflammatory agent, subacute toxicity test, oral, rats.

緒言

Mofezolac（以下N-22 と記す）は大鵬薬品工業株式会社で新しく開発されたイソキサゾー ル骨格を有する鎮痛抗炎症剤である。

今回著者らは, N-22の安全性評価の一環として, ラット経口投与による 3 力月間の亜急 性毒性を検討するとともに 1 力月間休薬による回復性についても検討したので報告する。

\section{材料および方法}

\section{1. 被験物質}

N-22の化学構造をFig. 1に示した。 


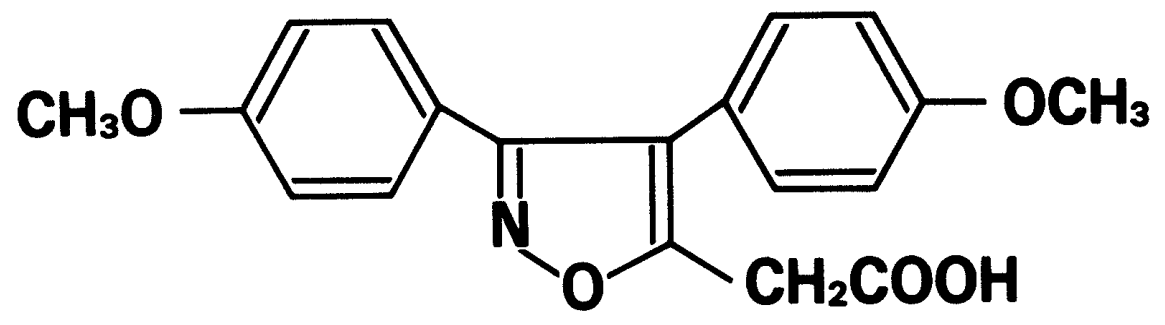

Fig. 1. Chemical structure of Mofezolac (N-22).

N-22 は化学名 [3, 4-di (4-methoxyphenyl)-5-isoxazolyl] acetic acidの白色結晶性の粉末 で，においはないかまたはわずかに特異なにおいがあり，ジメチルホルムアミドに極めて 溶けやすく, クロロホルムに溶けやすく, メタノール, エタノールまたはアセトンにやや 溶けやすく，エーテルまたは希水酸化ナトリウム試液にやや溶けにくく，水またはへキサ ンにほとんど溶けない化合物である。

本試験には大鵬薬品工業株式会社より提供されたN-22(Lot No. 1076. B-1, 含量 $100.1 \%$ ) を使用した。

\section{2. 試験動物および飼育条件}

日本クレア株式会社により 4 週㱓のWistar系ラット（SPF, Jcl：Wistar）雌雄各100匹を 購入し, 約 1 週間の予備飼育ののち体重の増加が良好で一般症状に異常の認められない健 康な動物を試験に使用した。投与開始時の体重範囲は雄136〜159g , 雌115 148g であっ た。試験期間中, ラットはブラケット式金属ケージに 1 ケージ 2 〜 匹ずつ収容し, 温度 $23 \pm 1{ }^{\circ} \mathrm{C}$, 湿度 $55 \pm 5 \%$, 換気回数 15 回/時間 (オールエアーフレッシュ方式), 照明時間 12 時間（午前 8 時〜午後 8 時）のバリアシステム飼育室で飼育した。固型飼料 (CRF-1： オリエンタル醉母工業株式会社）および水（水道水）は自由に摂取させた。

3 . 検体調製, 投与量および投与方法

$\mathrm{N}-22$ は0.5\% CMC（カルボキシメチルセルロース）水溶液でそれぞれ 2，0.6，0.2およ び0.06\%濃度となるように用時懸濁調製して使用した。

$\mathrm{N}-22$ の投与量は予備試験の結果を参考にして設定した。すなわち，N-22の $300 ， 90 ， 30$ ， $10 ， 3$ および $1 \mathrm{mg} / \mathrm{kg}$ を投与した結果, $300 \mathrm{mg} / \mathrm{kg}$ では死亡例がみられ, $90 \mathrm{mg} / \mathrm{kg}$ では回腸 の一部赤色化がみられた。 $30 \mathrm{mg} / \mathrm{kg}$ 以下では著変は認められなかった。従って, 本試験に おける投与量は $200,60,20$ およ゙ $6 \mathrm{mg} / \mathrm{kg}$ 亡し, 投与容量はいずれの群もラットの体重 $100 \mathrm{~g}$ 当たり $1.0 \mathrm{ml}$ とした。また，対照群には $0.5 \% \mathrm{CMC}$ 水溶液のみを投与した。

投与方法はディスポシリンジ（テルモ社）およびラット用金属製胃ゾンデを用いて強制 経口投与した。

4. 動物数および投与期間

動物数は各群とも雔雄各々 17 匹を用い，3 カ月間の投与期間終了時には各群10匹を剖検 (13週解剖群) し，残りの動物は 1 力月間休薬（回復群）ののち剖検した。 


\section{K. SHIMPO et al.}

なお， $200 \mathrm{mg} / \mathrm{kg}$ 群では途中死亡例が多数みられたため投与期間終了時に全例屠殺剖検し た。

5. 検査項目および方法

試験期間中, 一般状態の観察を毎日行うとともに, 体重はアニマルスケール（日本クレ ア(侏)）を使用して週 1 回測定した。摂餌量および摂水量は週 1 回ケージ毎に測定し， 1 匹 あたりの 1 日摄取量を算出した。投与期間終了日および回復期間終了日にはラットを代謝 ケージ（夏目製作所）に収容して 3 時間（12：00 15:00）の蓄尿を採取して定性的検查 をまた，21時間（12:00〜 9:00）の蓄積尿について定量的検查を行った。解剖時には エーテル麻酔下で血液学的検査および血液生化学的検査のための採血を行った。すなわち, 血液学的検査には股静脈より採取したEDTA・ $2 \mathrm{~K}$ 処理血液を用い，血液生化学的検查には 腹部大動脈より採血し，3000rpmで10分間遠心分離後得られた血清を用いた。上記臨床検 查の項目および方法をTable 1に示した。

動物は採血後直ちに放血致死させ, 全身諸藏器の病理解剖学的検査と主要臟器（脳, 下 垂体, 心, 胸腺, 肺, 肝, 腎, 脾, 副腎, 精巣, 子宮および卵巣) の重量を測定し, 相対 重量（体重比重量）を算出した。重量測定臓器のほかに胃, 十二指腸, 空腸, 回腸, 盲腸, 結腸, 膵, 腸間膜リンパ節, 筋肉 (大腿), 骨髄 (胸骨, 腰椎および大腿骨), 膀胱, 前立 腺, 精巣上体, 精蘘および病変部について $10 \%$ 中性緩衝ホルマリン液で固定後パラフィン 切片を作製し, ヘマトキシリン・エオジン（H.E.）染色を施して病理組織学的検査を行っ た。

\section{6 . 統計処理}

体重, 摄慨量, 摄水量, 尿検查 (定量的項目), 血液学的検査, 血液生化学的検查, 臓 器重量および相対重量についてはBartlettの方法によって等分散性を検定した。その結果, 等分散のものについては一元配置分散分析によって解析し, 有意な $(\mathrm{P}<0.05)$ 群間差が 認められた場合, Dunnettの方法により対照群とN-22投与各群との比較を行った。一方, 不等分散を示したものおよび尿検査（定性的項目）についてはKruskal-Wallisの方法により 解析し, 有意な群間差が認められた場合, Mann-Whitneyの方法により対照群とN-22投与 各群との比較を行った。

\section{結果}

\section{1. 一般状態の観察}

$200 \mathrm{mg} / \mathrm{kg}$ 群の雄 9 例, 雌13例が投与 4 13週に死亡した。死亡例はいずれも貧血, 血液 を混じた下㢉および削瘦を呈した。生存例では雌雄に投与 3 週頃より死亡例と同様の変化 のほか，鼻および口周囲の污染，立毛，自発運動の減少なざの症状が散見された。 そのほかの群には著変は認められなかった。

2. 体重の推移

各群の平均体重の推移をFig. 2に示した。 
$200 \mathrm{mg} / \mathrm{kg}$ 群では雄で投与 4 週頃より, 雌で投与 7 週頃より体重の増加抑制がみられた。 そのほかの群には著変は認められなかった。

3. 摂餌量の推移

摂嘅量の推移をFig. 3に示した。

$200 \mathrm{mg} / \mathrm{kg}$ 群では雄で投与 5 週頃より，雌で投与 6 週頃より摂餌量の減少ないし減少傾向 が認められた。

そのほかの群には著変は認められなかった。

4. 摄水量の推移

摄水量の推移をFig. 4に示した。

$200 \mathrm{mg} / \mathrm{kg}$ 群では雄で投与 7 週頃より軽度な増加傾向が認められたが，雌では著変はみら れなかった。

そのほかの群には著変は認められなかった。

5 . 尿検査

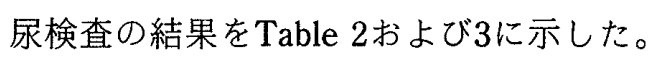

1) 13 週解剖群

$200 \mathrm{mg} / \mathrm{kg}$ 群と $60 \mathrm{mg} / \mathrm{kg}$ 群の雄では $\mathrm{pH}$ の低下と半数以上の例にウロビリノーゲンの陽性 化がみられた。60mg $/ \mathrm{kg}$ 群の雌ではpHの低下がみられた。 $20 \mathrm{mg} / \mathrm{kg}$ 群では雄に $\mathrm{pH}$ の低下が みられた。

そのほかの群には著変は認められなかった。

2 ) 回復群

6 および $60 \mathrm{mg} / \mathrm{kg}$ 群の雌に尿比重の上昇あるいは上昇傾向がみられた。 そのほかの群には著変は認められなかった。

6. 血液学的検査 血液学的検查の結果をTable 4 おび 5 に示した。

1 ) 13 週解剖群

$200 \mathrm{mg} / \mathrm{kg}$ 群では雌雄に RBC, $\mathrm{Ht}$ 值, $\mathrm{Hb}$ 量, MCHCの減少および網状赤血球率の増加が 認められた。さらに雄ではMCHの減少と白血球分類で好中球の増加およびリンパ球の減少 が，雌ではMCVの増加が認められた。60mg/kg群では雌に血小板数の減少を認めた。 そのほかの群には著変は認められなかった。

2 ) 回復群

$60 \mathrm{mg} / \mathrm{kg}$ 群の雌に MCVの減少がみられた。 そのほかの群には著変は認められなかった。

7. 血液生化学的検査

血液生化学的検査の結果をTable 6および7に示した。

1) 13 週解剖群

$200 \mathrm{mg} / \mathrm{kg}$ 群では雌雄に $\mathrm{ChE}, \mathrm{TP}, \mathrm{Alb}$ および $\mathrm{Cl}^{-}$の減少と $\mathrm{BUN}, \mathrm{UAお} よ ひ ゙ \mathrm{~K}^{+}$の増加が 
K. SHIMPO et al.

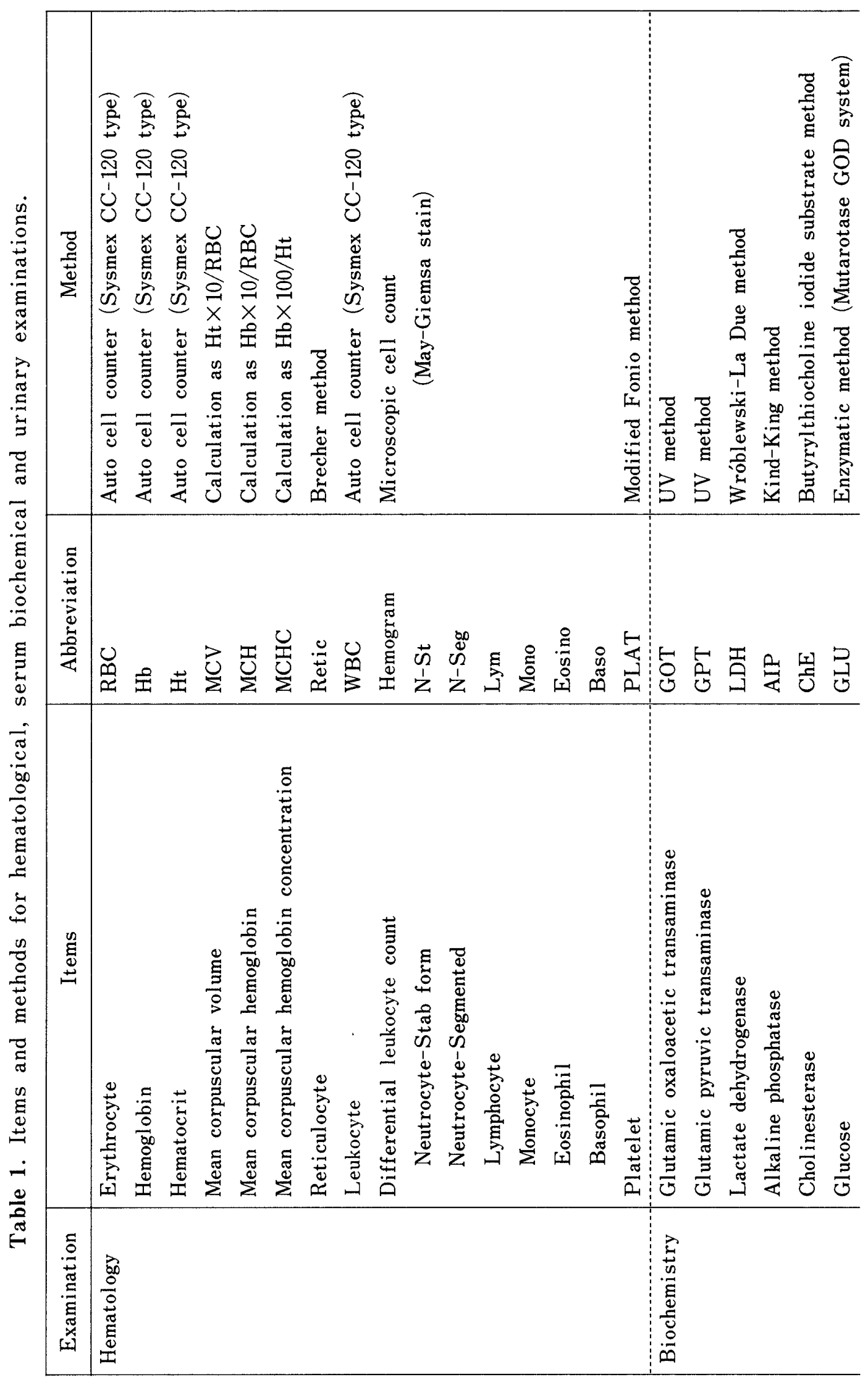


Subacute toxicity study of mofezolac $(\mathrm{N}-22)$ in rats

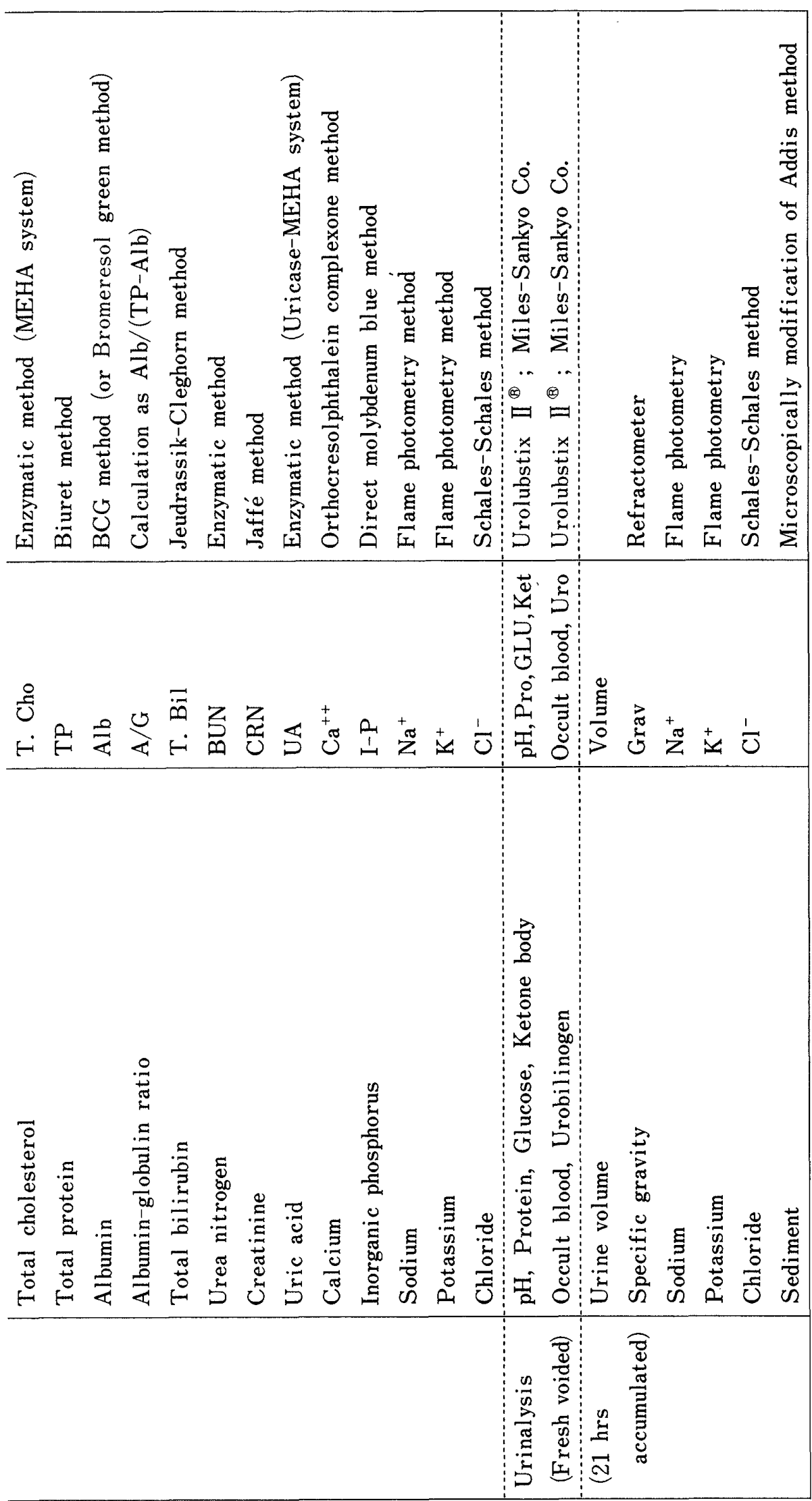



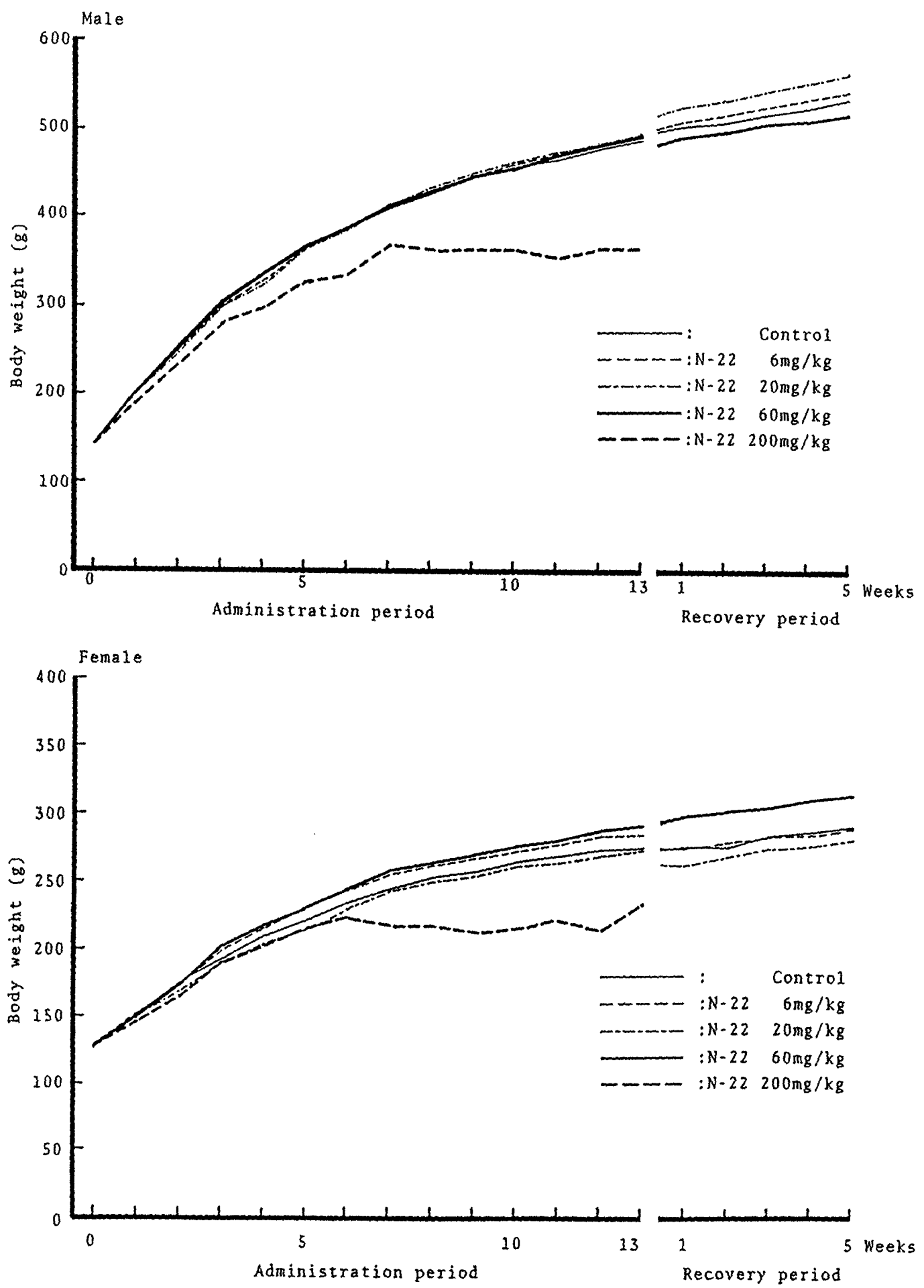

Fig. 2. Changes in mean body weight of male and female rats during the oral administration of $\mathrm{N}-22$ for 3 months and the recovery period for 1 month. 


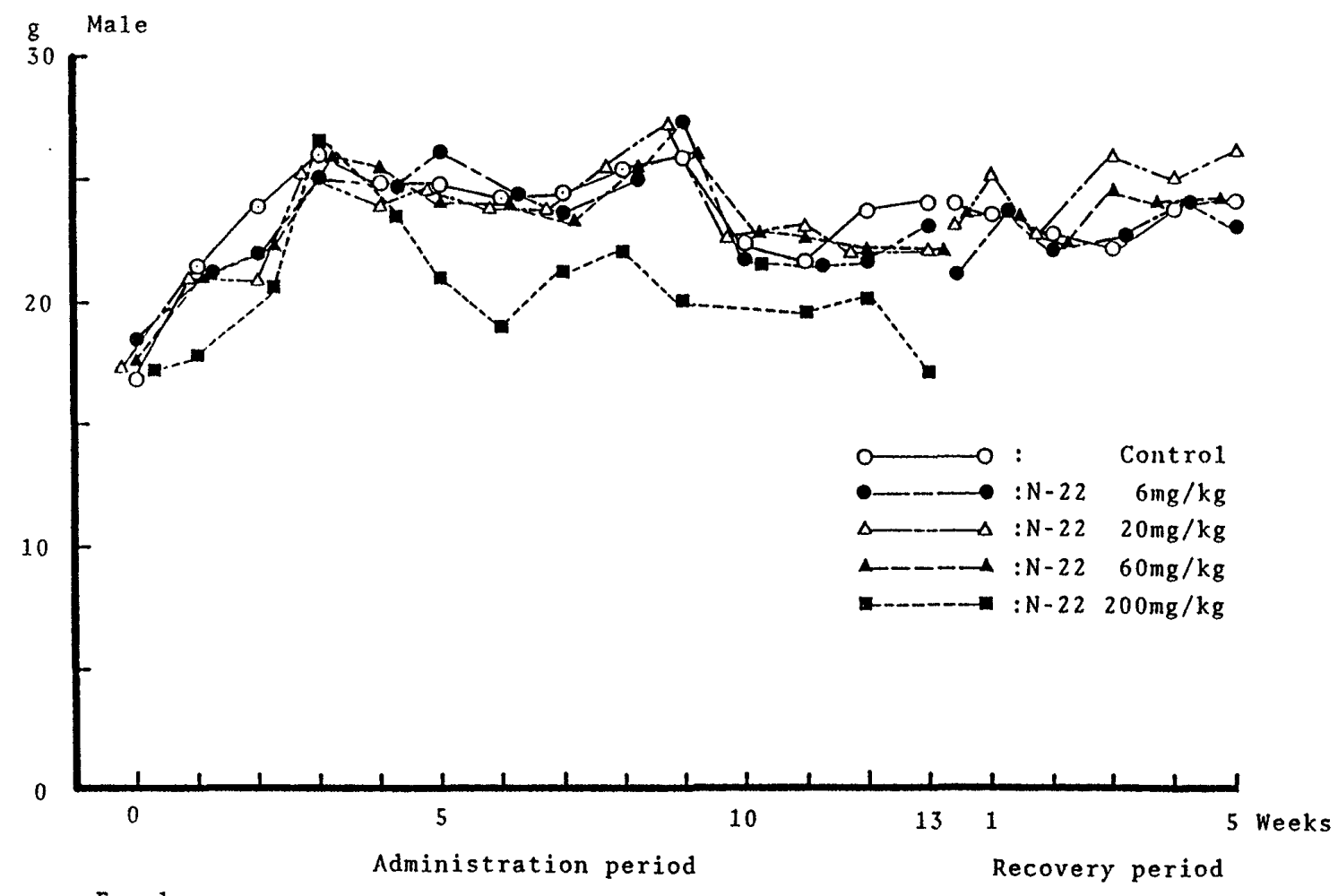

g Female

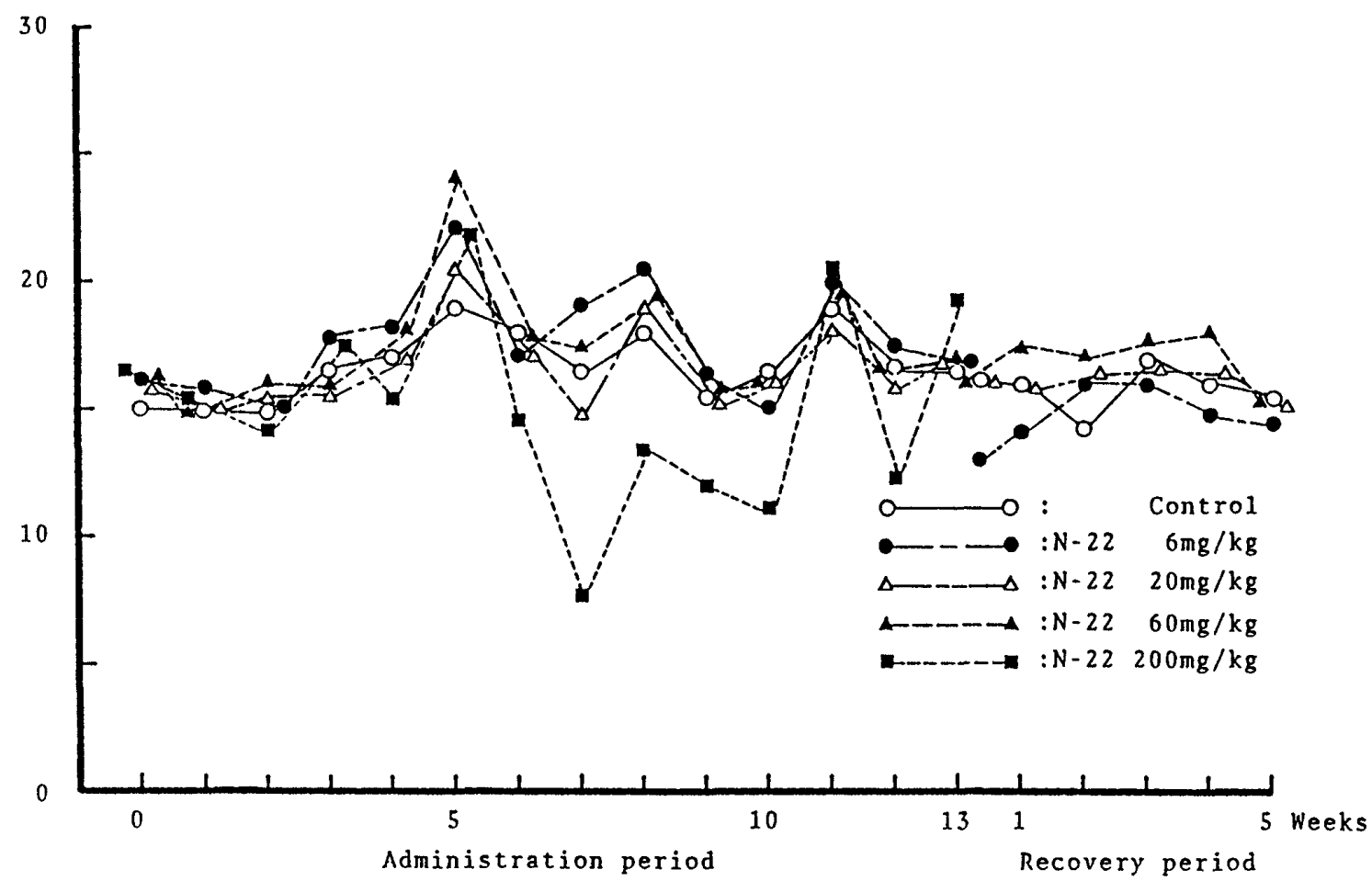

Fig. 3. Changes in mean food consumption in male and female rats during the oral administration of $\mathrm{N}-22$ for 3 months and the recovery period for 1 month. 

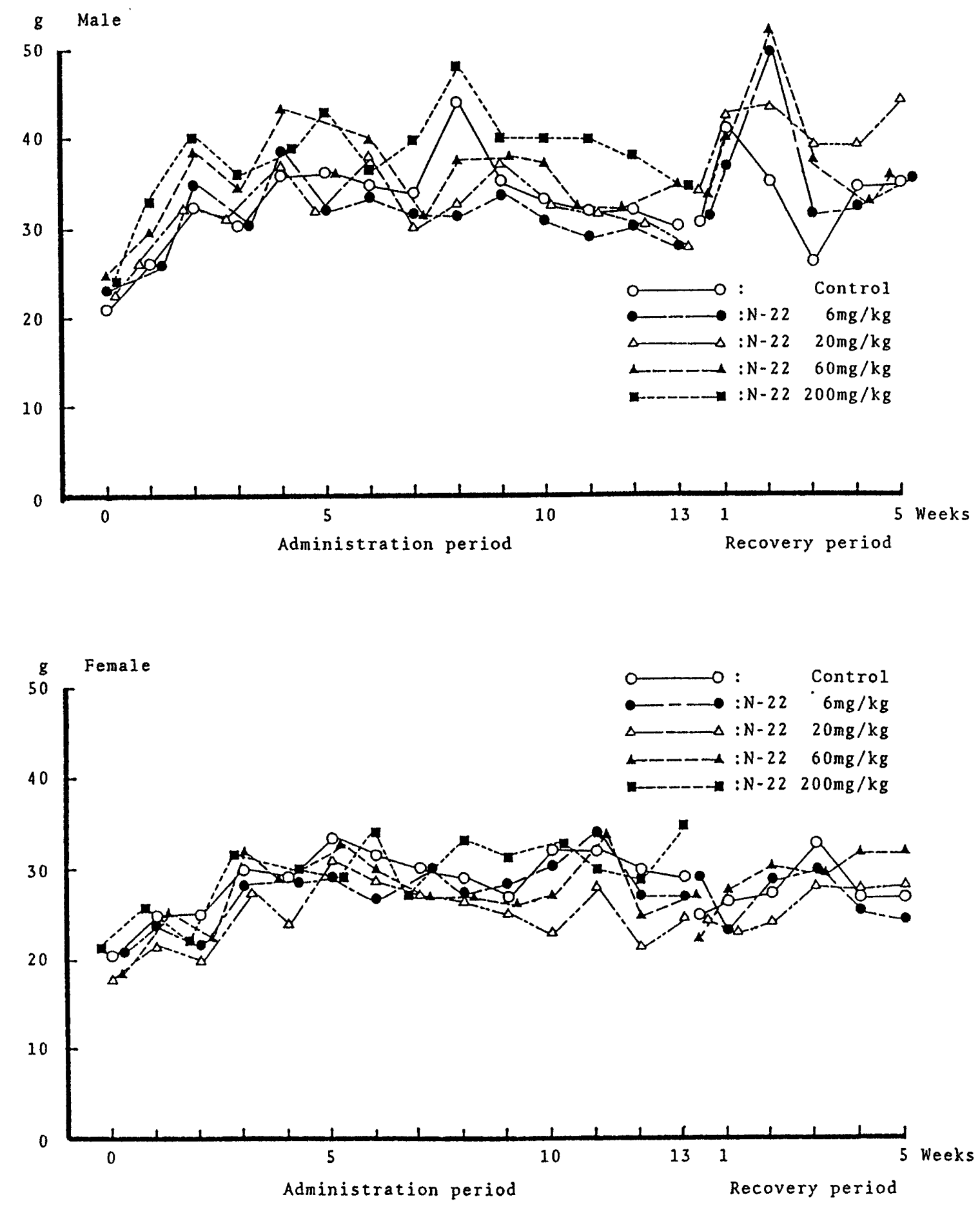

Fig. 4. Changes in mean water consumption in male and female rats during the oral administration of $\mathrm{N}-22$ for 3 months and the recovery period for 1 month. 
みられたほか, 雄にI-Pの増加およびCa ${ }^{++}$の減少が, 雌にA/G比の減少, GOTおよびLDH

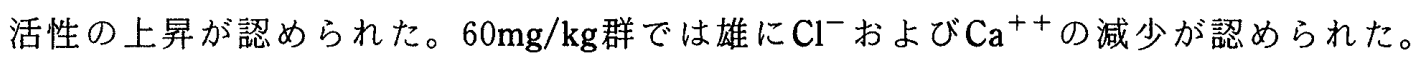
$20 \mathrm{mg} / \mathrm{kg}$ 群では雄に $\mathrm{Cl}^{-}$の減少が認められた。 $6 \mathrm{mg} / \mathrm{kg}$ 群には著変は認められなかった。

2 ) 回復群

$60 \mathrm{mg} / \mathrm{kg}$ 群の雄にA/G比, $\mathrm{Na}^{+} お よ ひ ゙ \mathrm{Ca}^{++}$の減少と $\mathrm{K}^{+}$の増加が, また, 雌にUAの増加 がみられた。

そのほかの群には著変は認められなかった。

8. 蔵器重量および相対重量

臟器重量および相対重量をTable 8〜11に示した。

1) 13 週解剖群

$200 \mathrm{mg} / \mathrm{kg}$ 群では雌雄に脾の重量増加がみられ, さらに雄では右副腎, 雌では肝の重量増 加が認められた。相対重量では $200 \mathrm{mg} / \mathrm{kg}$ 群の雌雄に脳, 肝, 脾, 腎および副腎の増加が, 雄ではさらに下垂体，心，肺および精巣の増加が認められた。

そのほかの群には著変は認められなかった。

2 ) 回復群

$60 \mathrm{mg} / \mathrm{kg}$ 群では雄に副腎および左精巣の重量増加ないし増加傾向が認められた。相対重 量では雄に副腎および左精巣の増加がみられた。 $20 \mathrm{mg} / \mathrm{kg}$ 群では雄に肺および副堅の重量 増加ないし増加傾向がみられた。相対重量では雄に右副腎の増加が, 雌に肝の増加がみら れた。 $6 \mathrm{mg} / \mathrm{kg}$ 群には著変は認められなかった。

9 . 病理解剖学的検査

1 ) 死亡動物

$200 \mathrm{mg} / \mathrm{kg}$ 群の死亡例では共通して, 透明胸水あるいは消化管内容物を含んだ混溜腹水の 貯留, 小腸の穿孔性潰瘍もしくは潰瘍とそれに伴う腹腔内諸㵴器の癒着, 胸腔内臓器の癒 着, 胸腺の萎縮, 肝および脾の裉色, 脾腫が認められ, 少数例に腸間膜りンパ節の腫大, 精霟および前立腺の萎縮などがみられた。

2) 13 週解剖群

$200 \mathrm{mg} / \mathrm{kg}$ 群では雌雄の少数例ないし約半数例に上記死亡動物にみられた小腸の潰瘍, 腹 腔内および胸腔内諸藏器の炎症性変化に加えて肝および脾の螁色, 脾腫, 腸間膜リンパ節 の腫大が認められた。そのほか, 対照群を含む雌各群に子宮内腔の拡張が散見された。

3 ) 回復群

$20 \mathrm{mg} / \mathrm{kg}$ 群の雄および $60 \mathrm{mg} / \mathrm{kg}$ 群の雌の各 1 例に胸腔内臟器の瘾着がみられた。そのほ か対照群を含む雄または雌の少数例に下顎リンパ節の腫大, 子宮内腔の拡張, 眼球白濁, 肺の肝変などが散見された。

10. 病理組織学的検査

病理組織学的検査結果をTable $12 お よ ひ ゙ 13 に$ 示した。 


\section{K. SHIMPO et al.}

Table 2. Urinary findings in male and female rats

\begin{tabular}{|c|c|c|c|c|c|c|}
\hline \multirow{2}{*}{\multicolumn{2}{|c|}{$\begin{array}{l}\text { Sex } \\
\text { Dose (mg/kg/day) }\end{array}$}} & \multicolumn{5}{|c|}{ Male } \\
\hline & & \multirow{2}{*}{$\begin{array}{c}\text { Control } \\
10 \\
\end{array}$} & \multirow{2}{*}{$\begin{array}{r}6 \\
10\end{array}$} & 20 & 60 & 200 \\
\hline & & & & 10 & 10 & 8 \\
\hline \multirow[t]{3}{*}{$\mathrm{pH}$} & $.0 \sim 7.0$ & $1^{\mathrm{a}}$ & 3 & 6 & 6 & 7 \\
\hline & $.5 \sim 8.0$ & 2 & 5 & $4\}^{* *}$ & $4\}^{* *}$ & 1 ** \\
\hline & $.5 \sim 9.0$ & 7 & 2 & 0 & $0^{\prime}$ & $0)$ \\
\hline \multirow[t]{3}{*}{ Pro } & - & 0 & 1 & 1 & 3 & 1 \\
\hline & trace & 8 & 9 & 8 & 5 & 6 \\
\hline & $+/ H$ & 2 & 0 & 1 & 2 & 1 \\
\hline GLU & - & 10 & 10 & 10 & 10 & 8 \\
\hline Ket & - & 10 & 10 & 10 & 10 & 8 \\
\hline \multirow[t]{2}{*}{ Uro } & \pm & 10 & 10 & 10 & \multirow{2}{*}{$\left.\begin{array}{l}3 \\
7\end{array}\right\} * *$} & $\left.{ }^{3}\right\}_{*}$ \\
\hline & $+/ H$ & 0 & 0 & 0 & & $5\}^{*}$ \\
\hline Occult & - & 10 & 10 & 10 & 9 & 7 \\
\hline blood & $+/ H$ & 0 & 0 & 0 & 1 & 1 \\
\hline \multicolumn{7}{|l|}{ Sediment } \\
\hline \multirow[t]{2}{*}{$\mathrm{RBC}$} & - & 10 & 10 & 10 & 9 & 7 \\
\hline & $\mathrm{A}$ & 0 & 0 & 0 & 1 & 1 \\
\hline WBC & - & 10 & 10 & 10 & 10 & 8 \\
\hline \multirow[t]{3}{*}{ Squa. EC } & - & 8 & 9 & 8 & 9 & 6 \\
\hline & \pm & 2 & 1 & 2 & 1 & 2 \\
\hline & + & 0 & 0 & 0 & 0 & 0 \\
\hline \multirow[t]{3}{*}{ Round EC } & $C-$ & 10 & 10 & 9 & 10 & 8 \\
\hline & \pm & 0 & 0 & 1 & 0 & 0 \\
\hline & + & 0 & 0 & 0 & 0 & 0 \\
\hline \multirow[t]{2}{*}{ S. R. EC } & - & 8 & 9 & 9 & 6 & 5 \\
\hline & \pm & 2 & 1 & 1 & 4 & 3 \\
\hline
\end{tabular}

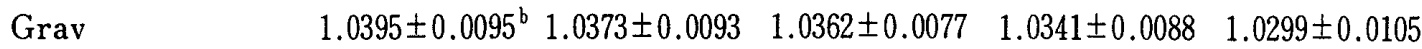

$\begin{array}{lllllll}\text { Volume } & \mathrm{ml} & 13.26 \pm 7.12 & 13.65 \pm 5.53 & 12.96 \pm 4.07 & 15.82 \pm 5.50 & 19.08 \pm 10.49\end{array}$

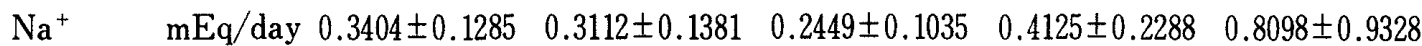

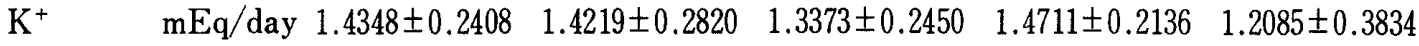

$\begin{array}{lllllll}\mathrm{Cl}^{-} & \mathrm{mEq} / \text { day } & 0.5271 \pm 0.1434 & 0.5126 \pm 0.1527 & 0.4051 \pm 0.1657 & 0.5397 \pm 0.2091 & 0.8308 \pm 0.6955\end{array}$

a: Values are no. of animals

b: Values are means \pm S. D.

$\mathrm{A}:$ male $=5 \sim 10 / \mathrm{HPF}$, female $=7 \sim 15 / \mathrm{HPF}$

: Differs from control $(\mathrm{P}<0.05)$

** : Differs from control $(\mathrm{P}<0.01)$ 
Subacute toxicity study of mofezolac $(\mathrm{N}-22)$ in rats

after oral administration of $\mathrm{N}-22$ for 3 months.

\begin{tabular}{|c|c|c|c|c|}
\hline \multicolumn{5}{|c|}{ Female } \\
\hline Control & 6 & 20 & 60 & 200 \\
\hline 10 & 10 & 10 & 10 & 4 \\
\hline 2 & 2 & 0 & 6 & 1 \\
\hline 2 & 0 & 2 & $2\} *$ & 2 \\
\hline 6 & 8 & 8 & $2^{1}$ & 1 \\
\hline 0 & 0 & 0 & $5)$ & 2 \\
\hline 6 & 3 & 4 & $4\} *$ & 2 \\
\hline 4 & 7 & 6 & $1)$ & 0 \\
\hline 10 & 10 & 10 & 10 & 4 \\
\hline 10 & 10 & 10 & 10 & 4 \\
\hline 9 & 9 & 7 & 7 & 2 \\
\hline 1 & 1 & 3 & 3 & 2 \\
\hline 10 & 10 & 10 & 10 & 3 \\
\hline 0 & 0 & 0 & 0 & 1 \\
\hline 10 & 10 & 10 & 10 & 3 \\
\hline 0 & 0 & 0 & 0 & 1 \\
\hline 10 & 10 & 10 & 10 & 4 \\
\hline 7 & 8 & 6 & 4 & 2 \\
\hline 3 & 2 & 4 & 4 & 2 \\
\hline 0 & 0 & 0 & 2 & 0 \\
\hline 9 & 9 & 9 & 7 & 4 \\
\hline 1 & 1 & 1 & 2 & 0 \\
\hline 0 & 0 & 0 & 1 & 0 \\
\hline 10 & 10 & 9 & 8 & 3 \\
\hline 0 & 0 & 1 & 2 & 1 \\
\hline $1.0413 \pm 0.0144$ & $1.0395 \pm 0.0128$ & $1.0407 \pm 0.0116$ & $1.0339 \pm 0.0097$ & $1.0253 \pm 0.0071$ \\
\hline $8.21 \pm 4.55$ & $8.97 \pm 5.42$ & $7.76 \pm 5.45$ & $10.33 \pm 3.68$ & $15.85 \pm 6.45$ \\
\hline $0.3812 \pm 0.1464$ & $0.2985 \pm 0.1144$ & $0.3456 \pm 0.1222$ & $0.3419 \pm 0.1748$ & $0.4458 \pm 0.2915$ \\
\hline $0.8491 \pm 0.1910$ & $0.9402 \pm 0.1664$ & $0.9231 \pm 0.2994$ & $0.8530 \pm 0.2745$ & $1.1155 \pm 0.1688$ \\
\hline $0.4671 \pm 0.1795$ & $0.5140 \pm 0.1681$ & $0.5020 \pm 0.2056$ & $0.4151 \pm 0.2016$ & $0.5623 \pm 0.2748$ \\
\hline
\end{tabular}




\section{K. SHIMPO et al.}

Table 3. Urinary findings in male and female rats allowed to recover

\begin{tabular}{|c|c|c|c|c|c|}
\hline \multirow{2}{*}{\multicolumn{2}{|c|}{$\begin{array}{l}\text { Sex } \\
\text { Dose (mg/kg/day) }\end{array}$}} & \multicolumn{4}{|c|}{ Male } \\
\hline & & \multirow{2}{*}{$\begin{array}{c}\text { Control } \\
7\end{array}$} & \multirow{2}{*}{$\begin{array}{l}6 \\
7\end{array}$} & \multirow{2}{*}{$\begin{array}{r}20 \\
7\end{array}$} & \multirow{2}{*}{$\begin{array}{r}60 \\
7\end{array}$} \\
\hline No. of Ani & imals & & & & \\
\hline \multirow[t]{3}{*}{$\mathrm{pH}$} & $6.0 \sim 7.0$ & $0^{\mathrm{a}}$ & 0 & 0 & 0 \\
\hline & $7.5 \sim 8.0$ & 2 & 1 & 2 & 1 \\
\hline & $8.5 \sim 9.0$ & 5 & 6 & 5 & 6 \\
\hline \multirow[t]{3}{*}{ Pro } & - & 0 & 0 & 0 & 0 \\
\hline & trace & 5 & 7 & 6 & 6 \\
\hline & + & 2 & 0 & 1 & 1 \\
\hline GLU & - & 7 & 7 & 7 & 7 \\
\hline Ket & - & 7 & 7 & 7 & 7 \\
\hline Uro & \pm & 7 & 7 & 7 & 7 \\
\hline Occult & - & 7 & 6 & 7 & 7 \\
\hline blood & + & 0 & 1 & 0 & 0 \\
\hline \multicolumn{6}{|l|}{ Sediment } \\
\hline $\mathrm{RBC}$ & - & 7 & 7 & 7 & 7 \\
\hline WBC & - & 7 & 7 & 7 & 7 \\
\hline \multirow[t]{3}{*}{ Squa. EC } & - & 3 & 2 & 4 & 3 \\
\hline & \pm & 4 & 4 & 2 & 4 \\
\hline & + & 0 & 1 & 1 & 0 \\
\hline \multirow[t]{3}{*}{ Round EC } & - & 7 & 7 & 6 & 7 \\
\hline & \pm & 0 & 0 & 1 & 0 \\
\hline & + & 0 & 0 & 0 & 0 \\
\hline \multirow[t]{2}{*}{ S.R.EC } & - & 5 & 6 & 6 & 6 \\
\hline & \pm & 2 & 1 & 1 & 1 \\
\hline Grav & & $1.0383 \pm 0.0107^{b}$ & $1.0437 \pm 0.0089$ & $1.0376 \pm 0.0086$ & $1.0367 \pm 0.0094$ \\
\hline Volume & $\mathrm{ml}$ & $12.99 \pm 5.76$ & $10.29 \pm 3.86$ & $15.19 \pm 8.44$ & $13.76 \pm 4.25$ \\
\hline $\mathrm{Na}^{+}$ & $\mathrm{mEq} /$ day & $0.3440 \pm 0.0908$ & $0.3289 \pm 0.1645$ & $0.4571 \pm 0.2827$ & $0.3491 \pm 0.1329$ \\
\hline $\mathrm{K}^{+}$ & $\mathrm{mEq} /$ day & $1 . \dot{3} 411 \pm 0.1518$ & $1.3306 \pm 0.2144$ & $1.4621 \pm 0.3050$ & $1.3797 \pm 0.1904$ \\
\hline $\mathrm{Cl}^{-}$ & $\mathrm{mEq} /$ day & $0.5196 \pm 0.1239$ & $0.5180 \pm 0.2097$ & $0.6271 \pm 0.2081$ & $0.6149 \pm 0.1717$ \\
\hline
\end{tabular}


Subacute toxicity study of mofezolac $(\mathrm{N}-22)$ in rats

for 1 month after oral administration of $\mathrm{N}-22$ for 3 months.

\begin{tabular}{|c|c|c|c|}
\hline \multicolumn{4}{|c|}{ Female } \\
\hline Control & 6 & 20 & 60 \\
\hline 7 & 7 & 7 & 7 \\
\hline 2 & 3 & 4 & 1 \\
\hline 1 & 1 & 1 & 1 \\
\hline 4 & 3 & 2 & 5 \\
\hline 0 & 0 & 0 & 1 \\
\hline 4 & 4 & 3 & 6 \\
\hline 3 & 3 & 4 & 0 \\
\hline 7 & 7 & 7 & 7 \\
\hline 7 & 7 & 7 & 7 \\
\hline 7 & 7 & 7 & 7 \\
\hline 7 & 7 & 7 & 7 \\
\hline 0 & 0 & 0 & 0 \\
\hline 7 & 7 & 7 & 7 \\
\hline 7 & 7 & 7 & 7 \\
\hline 3 & 5 & 3 & 3 \\
\hline 4 & 2 & 4 & 4 \\
\hline 0 & 0 & 0 & 0 \\
\hline 7 & 7 & 7 & 4 \\
\hline 0 & 0 & 0 & 2 \\
\hline 0 & 0 & 0 & 1 \\
\hline 7 & 6 & 5 & 7 \\
\hline 0 & 1 & 2 & 0 \\
\hline $1.0336 \pm 0.0057$ & $1.0491 \pm 0.0083^{* *}$ & $1.0399 \pm 0.0119$ & $1.0433 \pm 0.0051$ \\
\hline $9.91 \pm 3.42$ & $5.21 \pm 1.84$ & $8.63 \pm 5.46$ & $6.23 \pm 0.97$ \\
\hline $0.2519 \pm 0.1008$ & $0.3730 \pm 0.1020$ & $0.3610 \pm 0.1601$ & $0.3696 \pm 0.0900$ \\
\hline $0.7567 \pm 0.1830$ & $0.8966 \pm 0.1995$ & $0.7850 \pm 0.2949$ & $0.7736 \pm 0.1673$ \\
\hline $0.3771 \pm 0.1403$ & $0.5210 \pm 0.1267$ & $0.4690 \pm 0.2574$ & $0.4644 \pm 0.0783$ \\
\hline
\end{tabular}


K. SHIMPO et al.

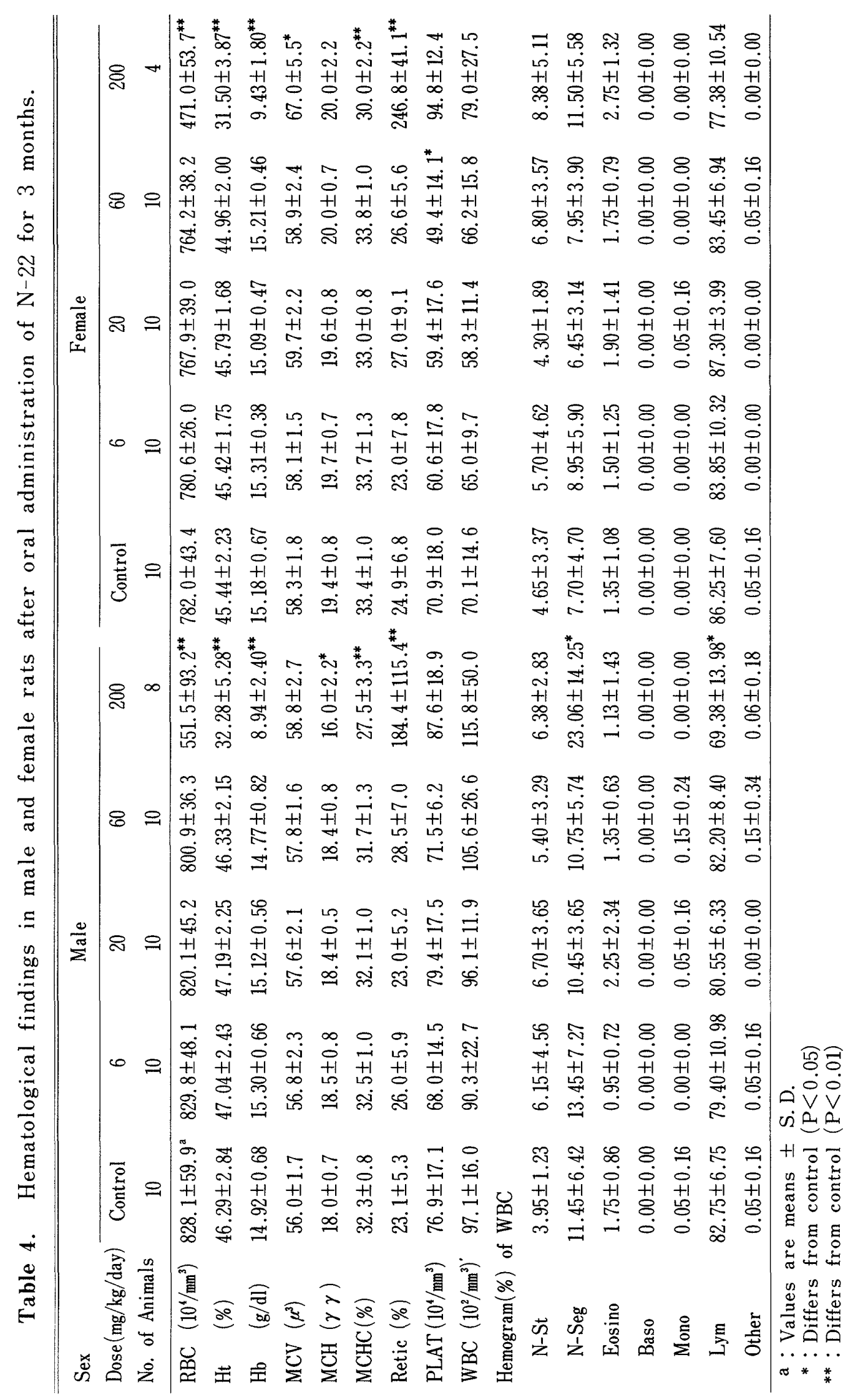


Subacute toxicity study of mofezolac $(\mathrm{N}-22)$ in rats

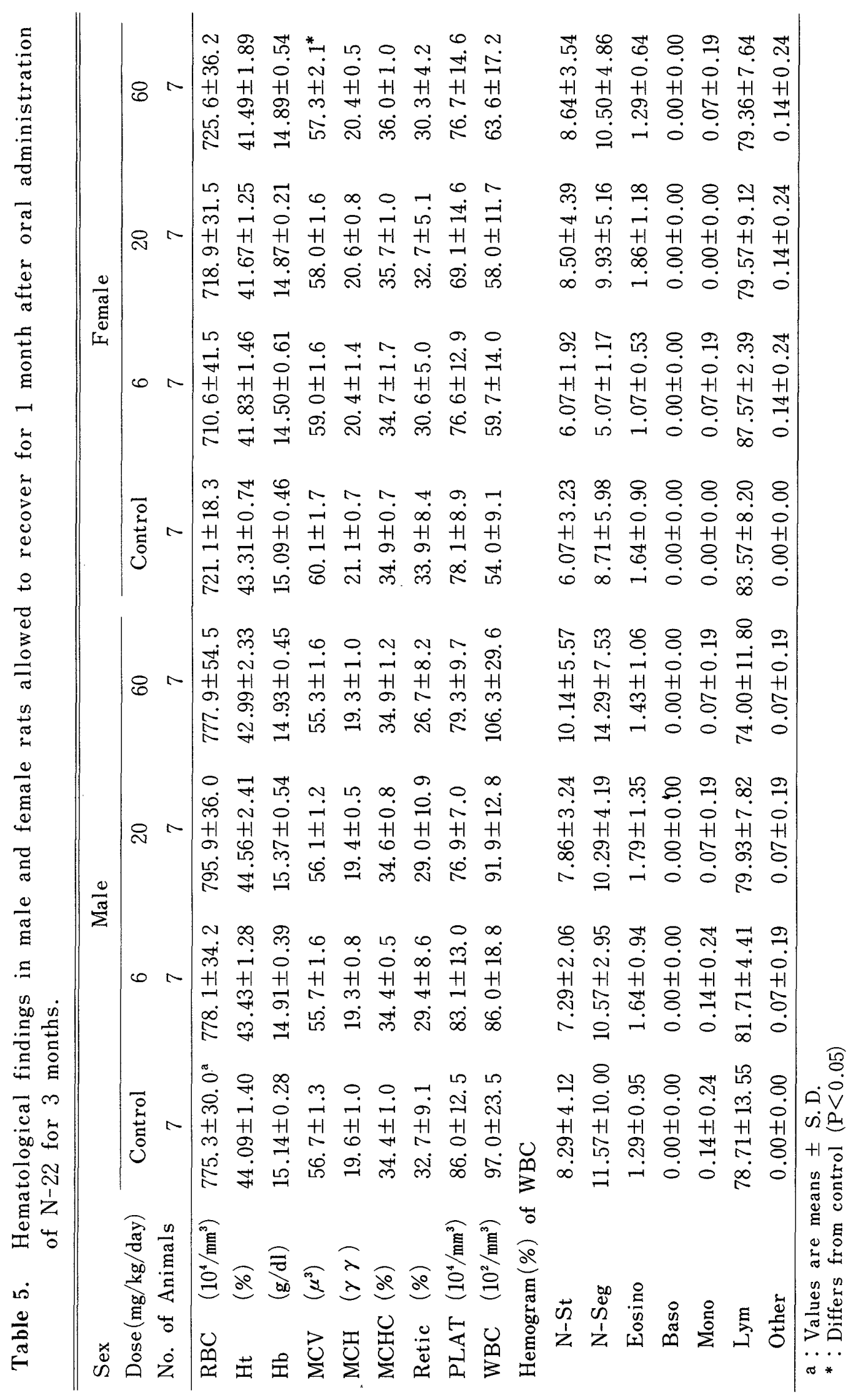


K. SHIMPO et al.

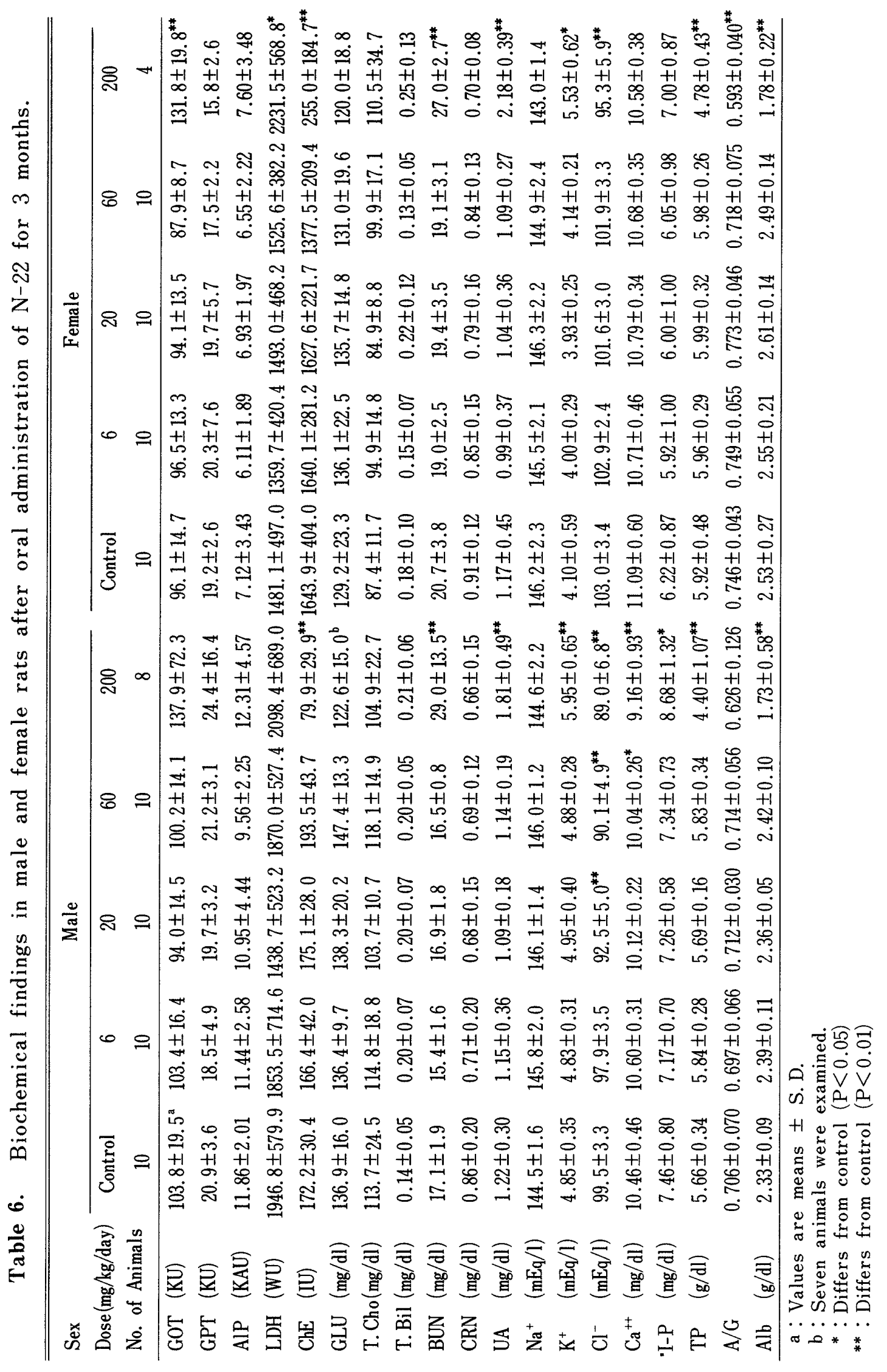


Subacute toxicity study of mofezolac $(\mathrm{N}-22)$ in rats

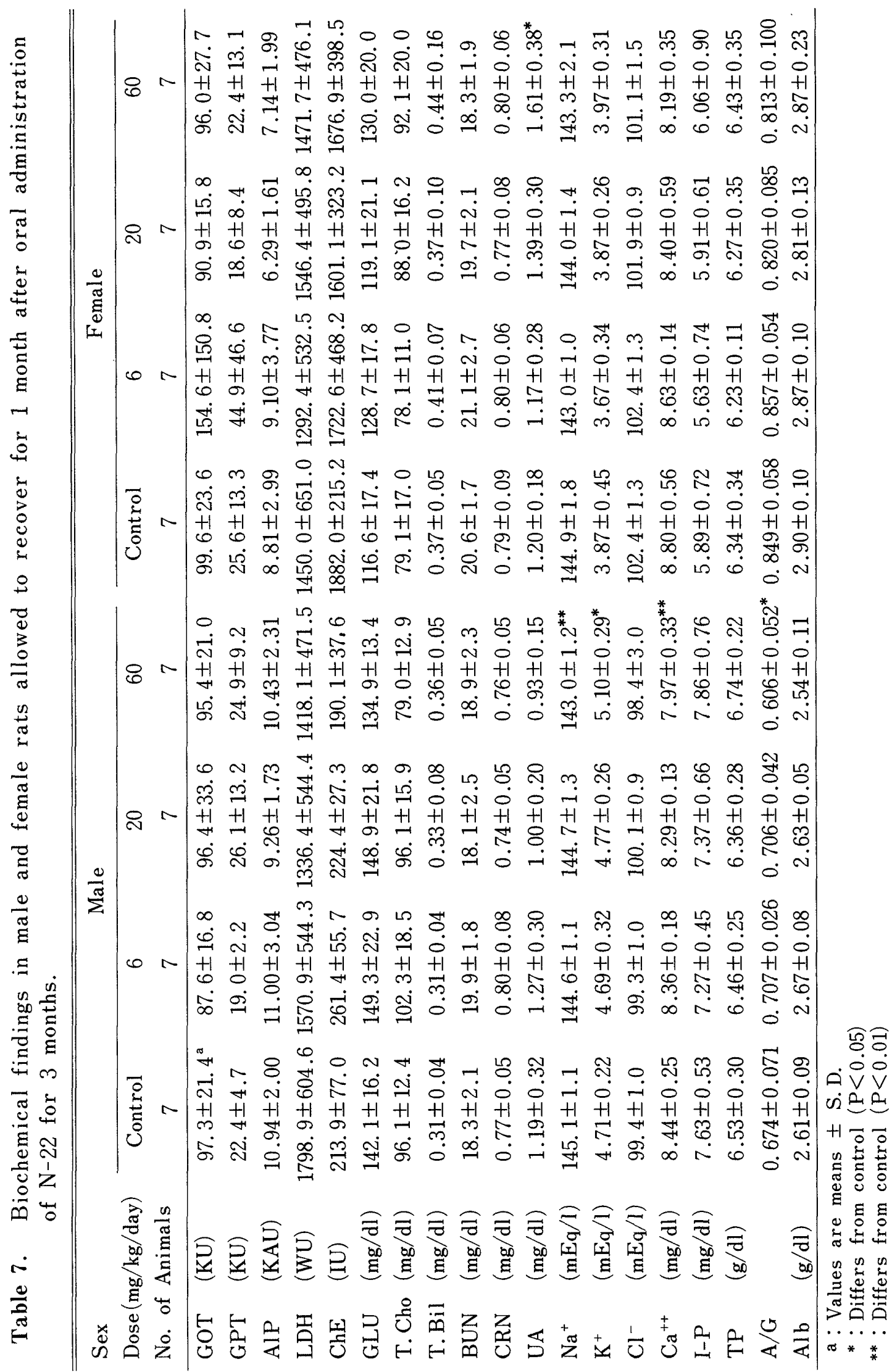




\section{K. SHIMPO et al.}

Table 8. Absolute organ weights in male and female rats after oral administration of $\mathrm{N}-22$ for 3 months.

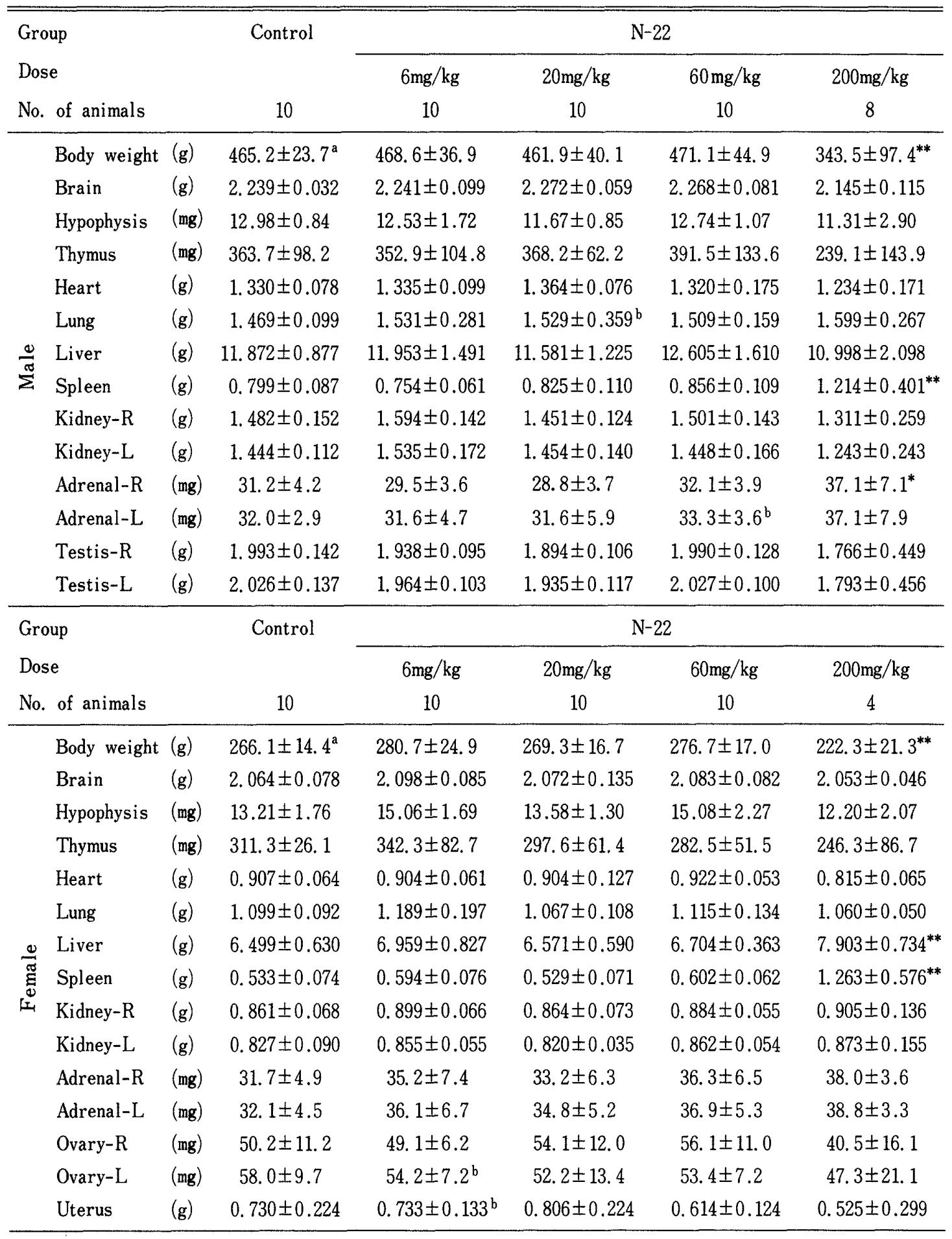

a: Values are means \pm S. D.

$\mathrm{b}$ : Nine animals were examined.

*: Differs from control $(\mathrm{P}<0.05)$

** : Differs from control $(\mathrm{P}<0.01)$ 
Subacute toxicity study of mofezolac $(\mathrm{N}-22)$ in rats

Table 9. Relative organ weights in male and female rats after oral administration of $\mathrm{N}-22$ for 3 months.

\begin{tabular}{|c|c|c|c|c|c|c|}
\hline \multirow{2}{*}{\multicolumn{2}{|c|}{$\begin{array}{l}\text { Group } \\
\text { Dose }\end{array}$}} & \multirow[t]{2}{*}{ Control } & \multicolumn{4}{|c|}{$\mathrm{N}-22$} \\
\hline & & & $6 \mathrm{mg} / \mathrm{kg}$ & $20 \mathrm{mg} / \mathrm{kg}$ & $60 \mathrm{mg} / \mathrm{kg}$ & $200 \mathrm{mg} / \mathrm{kg}$ \\
\hline \multicolumn{2}{|c|}{ No. of animals } & 10 & 10 & 10 & 10 & 8 \\
\hline \multirow{13}{*}{$\frac{0}{\sum^{\pi}}$} & Brain & $0.482 \pm 0.027^{\mathrm{a}}$ & $0.479 \pm 0.038$ & $0.495 \pm 0.037$ & $0.484 \pm 0.045$ & $0.685 \pm 0.251^{* *}$ \\
\hline & Hypophysis $\left(\% / 10^{3}\right)$ & $2.80 \pm 0.19$ & $2.66 \pm 0.28$ & $2.55 \pm 0.17$ & $2.72 \pm 0.29$ & $3.35 \pm 0.39^{* *}$ \\
\hline & Thymus $\quad\left(\% / 10^{3}\right)$ & $78.11 \pm 20.16$ & $75.10 \pm 20.93$ & $79.37 \pm 8.30$ & $82.70 \pm 23.86$ & $63.06 \pm 31.24$ \\
\hline & Heart & $0.286 \pm 0.013$ & $0.285 \pm 0.021$ & $0.296 \pm 0.026$ & $0.279 \pm 0.026$ & $0.381 \pm 0.097^{* *}$ \\
\hline & Lung & $0.314 \pm 0.012$ & $0.327 \pm 0.061$ & $0.337 \pm 0.090^{b}$ & $0.322 \pm 0.027$ & $0.530 \pm 0.268^{* *}$ \\
\hline & Liver & $2.554 \pm 0.180$ & $2.547 \pm 0.187$ & $2.507 \pm 0.128$ & $2.670 \pm 0.152$ & $3.383 \pm 0.952^{* *}$ \\
\hline & Spleen $\quad(\%)$ & $0.172 \pm 0.019$ & $0.160 \pm 0.016$ & $0.181 \pm 0.023$ & $0.183 \pm 0.025$ & $0.404 \pm 0.237^{* *}$ \\
\hline & Kidney-R (\%) & $0.320 \pm 0.034$ & $0.341 \pm 0.016$ & $0.313 \pm 0.019$ & $0.319 \pm 0.023$ & $0.399 \pm 0.078^{*}$ \\
\hline & Kidney-L $\quad(\%)$ & $0.311 \pm 0.025$. & $0.328 \pm 0.021$ & $0.316 \pm 0.017$ & $0.309 \pm 0.026$ & $0.376 \pm 0.081^{*}$ \\
\hline & Adrenal-R $\left(\% / 10^{3}\right)$ & $6.73 \pm 0.86$ & $6.33 \pm 0.93$ & $6.26 \pm 0.87$ & $6.88 \pm 1.20$ & $12.56 \pm 7.21^{* *}$ \\
\hline & Adrenal-L $\left(\% / 10^{3}\right)$ & $6.89 \pm 0.60$ & $6.77 \pm 1.03$ & $6.85 \pm 1.07$ & $6.90 \pm 1.18$ & $12.63 \pm 7.52^{* *}$ \\
\hline & Testis-R (\%) & $0.430 \pm 0.034$ & $0.415 \pm 0.030$ & $0.412 \pm 0.044$ & $0.426 \pm 0.048$ & $0.523 \pm 0.064^{* *}$ \\
\hline & Testis-L (\%) & $0.435 \pm 0.031$ & $0.420 \pm 0.027$ & $0.422 \pm 0.048$ & $0.433 \pm 0.043$ & $0.530 \pm 0.066^{* *}$ \\
\hline \multirow{2}{*}{\multicolumn{2}{|c|}{$\begin{array}{l}\text { Group } \\
\text { Dose }\end{array}$}} & Control & \multicolumn{4}{|c|}{$\mathrm{N}-22$} \\
\hline & & & $6 \mathrm{mg} / \mathrm{kg}$ & $20 \mathrm{mg} / \mathrm{kg}$ & $60 \mathrm{mg} / \mathrm{kg}$ & $200 \mathrm{mg} / \mathrm{kg}$ \\
\hline \multicolumn{2}{|c|}{ No. of animals } & 10 & 10 & 10 & 10 & 4 \\
\hline \multirow{14}{*}{ 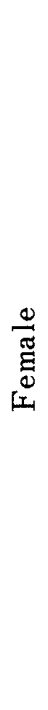 } & Brain $(\%)$ & $0.777 \pm 0.053$ & $0.751 \pm 0.068$ & $0.772 \pm 0.063$ & $0.755 \pm 0.034$ & $0.928 \pm 0.094^{* *}$ \\
\hline & Hypophysis $\left(\% / 10^{3}\right)$ & $4.97 \pm 0.58$ & $5.38 \pm 0.65$ & $5.05 \pm 0.41$ & $5.48 \pm 0.85$ & $5.45 \pm 0.48$ \\
\hline & Thymus $\quad\left(\% / 10^{3}\right)$ & $117.33 \pm 11.83$ & $122.81 \pm 29.77$ & $110.61 \pm 22.45$ & $101.94 \pm 15.80$ & $110.95 \pm 39.00$ \\
\hline & Heart & $0.340 \pm 0.030$ & $0.323 \pm 0.028$ & $0.336 \pm 0.032$ & $0.333 \pm 0.016$ & $0.370 \pm 0.049$ \\
\hline & Lung & $0.411 \pm 0.029$ & $0.429 \pm 0.104$ & $0.395 \pm 0.027$ & $0.403 \pm 0.043$ & $0.483 \pm 0.057$ \\
\hline & Liver & $2.441 \pm 0.191$ & $2.475 \pm 0.114$ & $2.438 \pm 0.125$ & $2.428 \pm 0.114$ & $3.595 \pm 0.603^{* *}$ \\
\hline & Spleen $\quad(\%)$ & $0.200 \pm 0.019$ & $0.212 \pm 0.022$ & $0.196 \pm 0.020$ & $0.218 \pm 0.022$ & $0.588 \pm 0.318^{* *}$ \\
\hline & Kidney-R (\%) & $0.325 \pm 0.026$ & $0.321 \pm 0.021$ & $0.320 \pm 0.021$ & $0.320 \pm 0.031$ & $0.405 \pm 0.024^{* *}$ \\
\hline & Kidney-L $\quad(\%)$ & $0.310 \pm 0.031$ & $0.305 \pm 0.018$ & $0.306 \pm 0.020$ & $0.312 \pm 0.026$ & $0.393 \pm 0.032^{* *}$ \\
\hline & Adrenal-R $\left(\% / 10^{3}\right)$ & $11.93 \pm 1.98$ & $12.55 \pm 2.35$ & $12.30 \pm 2.12$ & $13.18 \pm 2.59$ & $17.18 \pm 1.92^{* *}$ \\
\hline & Adrenal-L $\left(\% / 10^{3}\right)$ & $12.05 \pm 1.38$ & $12.91 \pm 2.34$ & $12.92 \pm 1.78$ & $13.37 \pm 1.99$ & $17.60 \pm 2.79^{* *}$ \\
\hline & Ovary-R $\quad\left(\% / 10^{3}\right)$ & $18.86 \pm 3.83$ & $17.56 \pm 2.13$ & $19.98 \pm 3.49$ & $20.27 \pm 3.66$ & $18.00 \pm 6.13$ \\
\hline & Ovary-L & $21.84 \pm 3.50$ & $19.36 \pm 2.35^{b}$ & $19.28 \pm 4.42$ & $19.32 \pm 2.46$ & $21.03 \pm 8.69$ \\
\hline & Uterus & $0.275 \pm 0.080$ & $0.261 \pm 0.043^{b}$ & $0.302 \pm 0.090$ & $0.223 \pm 0.044$ & $0.230 \pm 0.105$ \\
\hline
\end{tabular}

a: Values are means \pm S. D.

$\mathrm{b}$ : Nine animals were examined.

* : Differs from control $(\mathrm{P}<0.05)$

** : Differs from control $(\mathrm{P}<0.01)$ 


\section{K. SHIMPO et al.}

Table 10. Absolute organ weights in male and female rats allowed to recover for 1 month after oral administration of $\mathrm{N}-22$ for 3 months.

\begin{tabular}{|c|c|c|c|c|c|c|}
\hline \multirow{2}{*}{\multicolumn{3}{|c|}{$\begin{array}{l}\text { Group } \\
\text { Dose }\end{array}$}} & \multirow[t]{2}{*}{ Control } & \multicolumn{3}{|c|}{$\mathrm{N}-22$} \\
\hline & & & & $6 \mathrm{mg} / \mathrm{kg}$ & $20 \mathrm{mg} / \mathrm{kg}$ & $60 \mathrm{mg} / \mathrm{kg}$ \\
\hline & of animals & & 7 & 7 & 7 & 7 \\
\hline \multirow{14}{*}{ 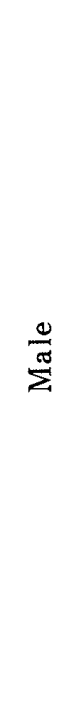 } & Body weight & $(\mathrm{g})$ & $507.0 \pm 32.2^{\mathrm{a}}$ & $517.9 \pm 49.5$ & $533.9 \pm 42.1$ & 494. $6 \pm 24.4$ \\
\hline & Brain & $(\mathrm{g})$ & 2. $316 \pm 0.127$ & $2.363 \pm 0.072$ & $2.283 \pm 0.086$ & $2.289 \pm 0.107$ \\
\hline & Hypophys is & (mg) & $13.17 \pm 2.33$ & $13.10 \pm 1.20$ & $15.71 \pm 1.61$ & $13.77 \pm 3.22^{b}$ \\
\hline & Thymus & (mg) & $264.1 \pm 71.4$ & $271.0 \pm 84.9$ & $325.7 \pm 96.2$ & $239.7 \pm 27.0$ \\
\hline & Heart & $(\mathrm{g})$ & $1.413 \pm 0.048$ & 1. $363 \pm 0.128$ & $1.557 \pm 0.177$ & $1.351 \pm 0.125$ \\
\hline & Lung & (g) & $1.407 \pm 0.064$ & 1. $429 \pm 0.111$ & 1. $647 \pm 0.168^{*}$ & $1.517 \pm 0.188$ \\
\hline & Liver & (g) & $12.597 \pm 0.859$ & $12.420 \pm 2.142$ & 13. $274 \pm 1.857$ & $11.916 \pm 1.162$ \\
\hline & Spleen & (g) & $0.830 \pm 0.034$ & $0.799 \pm 0.107$ & $0.846 \pm 0.100$ & $0.867 \pm 0.060$ \\
\hline & Kidney-R & (g) & $1.417 \pm 0.140$ & 1. $406 \pm 0.242$ & 1. $569 \pm 0.132$ & $1.520 \pm 0.156$ \\
\hline & Kidney-L & $(\mathrm{g})$ & 1. $349 \pm 0.107$ & 1. $411 \pm 0.236$ & $1.514 \pm 0.144$ & 1. $463 \pm 0.135$ \\
\hline & Adrenal-R & (mg) & $24.4 \pm 2.3$ & $26.1 \pm 3.0$ & $30.6 \pm 3.4^{*}$ & $30.0 \pm 5.4^{*}$ \\
\hline & Adrenal-L & (mg) & $25.6 \pm 3.6$ & $26.7 \pm 3.8$ & $28.9 \pm 4.6$ & $32.4 \pm 4.1^{*}$ \\
\hline & Testis-R & $(\mathrm{g})$ & $1.856 \pm 0.121$ & $1.934 \pm 0.080$ & $2.051 \pm 0.216$ & $2.020 \pm 0.092$ \\
\hline & Testis-L & $(\mathrm{g})$ & $1.900 \pm 0.126$ & $1.954 \pm 0.099$ & $2.056 \pm 0.177$ & $2.080 \pm 0.066^{*}$ \\
\hline \multirow{2}{*}{\multicolumn{3}{|c|}{$\begin{array}{l}\text { Group } \\
\text { Dose }\end{array}$}} & Control & \multicolumn{3}{|c|}{$\mathrm{N}-22$} \\
\hline & & & & $6 \mathrm{mg} / \mathrm{kg}$ & $20 \mathrm{mg} / \mathrm{kg}$ & $60 \mathrm{mg} / \mathrm{kg}$ \\
\hline & of animals & & 7 & 7 & 7 & 7 \\
\hline \multirow{15}{*}{ 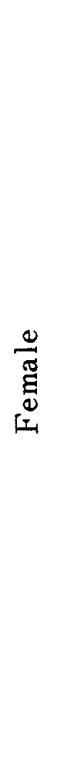 } & Body weight & $(\mathrm{g})$ & $276.1 \pm 24.2$ & $279.0 \pm 17.4$ & $266.9 \pm 19.9$ & $299.1 \pm 31.0$ \\
\hline & Brain & (g) & $2.046 \pm 0.098$ & $2.133 \pm 0.028$ & 2. $120 \pm 0.084$ & 2. $149 \pm 0.101$ \\
\hline & Hypophys is & (mg) & $16.24 \pm 4.06$ & $17.01 \pm 2.57$ & $16.93 \pm 2.91$ & $14.54 \pm 2.32$ \\
\hline & Thymus & (mg) & $244.0 \pm 67.7$ & $264.6 \pm 55.9$ & $221.3 \pm 47.5$ & $271.1 \pm 81.7$ \\
\hline & Heart & $(\mathrm{g})$ & $0.824 \pm 0.055$ & $0.860 \pm 0.063$ & $0.830 \pm 0.082$ & $0.927 \pm 0.114$ \\
\hline & Lung & (g) & $1.006 \pm 0.055$ & $1.083 \pm 0.088$ & $1.036 \pm 0.104$ & 1. $200 \pm 0.260^{b}$ \\
\hline & Liver & (g) & $6.216 \pm 0.504$ & $6.519 \pm 0.407$ & 6. $553 \pm 0.668$ & $6.869 \pm 0.680$ \\
\hline & Spleen & (g) & $0.524 \pm 0.084$ & $0.539 \pm 0.041$ & $0.534 \pm 0.079$ & $0.581 \pm 0.094$ \\
\hline & Kidney-R & (g) & $0.839 \pm 0.072$ & $0.859 \pm 0.081$ & $0.861 \pm 0.108$ & $0.897 \pm 0.125$ \\
\hline & Kidney-L & (g) & $0.823 \pm 0.057$ & $0.808 \pm 0.057^{b}$ & $0.830 \pm 0.109$ & $0.909 \pm 0.160$ \\
\hline & Adrenal-R & (mg) & 31. $1 \pm 6.1$ & $30.3 \pm 2.8$ & $32.6 \pm 5.6$ & $30.9 \pm 6.8$ \\
\hline & Adrenal-L & (mg) & 33. $1 \pm 3.8$ & $30.5 \pm 3.7^{b}$ & $33.4 \pm 4.6$ & $28.9 \pm 5.0$ \\
\hline & Ovary-R & (mg) & $43.6 \pm 10.5$ & $47.4 \pm 5.5$ & $44.6 \pm 9.7$ & $48.0 \pm 9.8$ \\
\hline & Ovary-L & (mg) & $48.7 \pm 8.8$ & $44.3 \pm 6.3$ & $46.7 \pm 11.5$ & $48.0 \pm 11.5$ \\
\hline & Uterus & $(\mathrm{g})$ & $0.750 \pm 0.277$ & $0.637 \pm 0.154$ & $0.614 \pm 0.215$ & $0.671 \pm 0.234$ \\
\hline
\end{tabular}

a: Values are means \pm S. D.

b: Six animals were examined.

*: Differs from control $(\mathrm{P}<0.05)$ 
Subacute toxicity study of mofezolac $(\mathrm{N}-22)$ in rats

Table 11. Relative organ weights in male and female rats allowed to recover for 1 month after oral administration of $\mathrm{N}-22$ for 3 months.

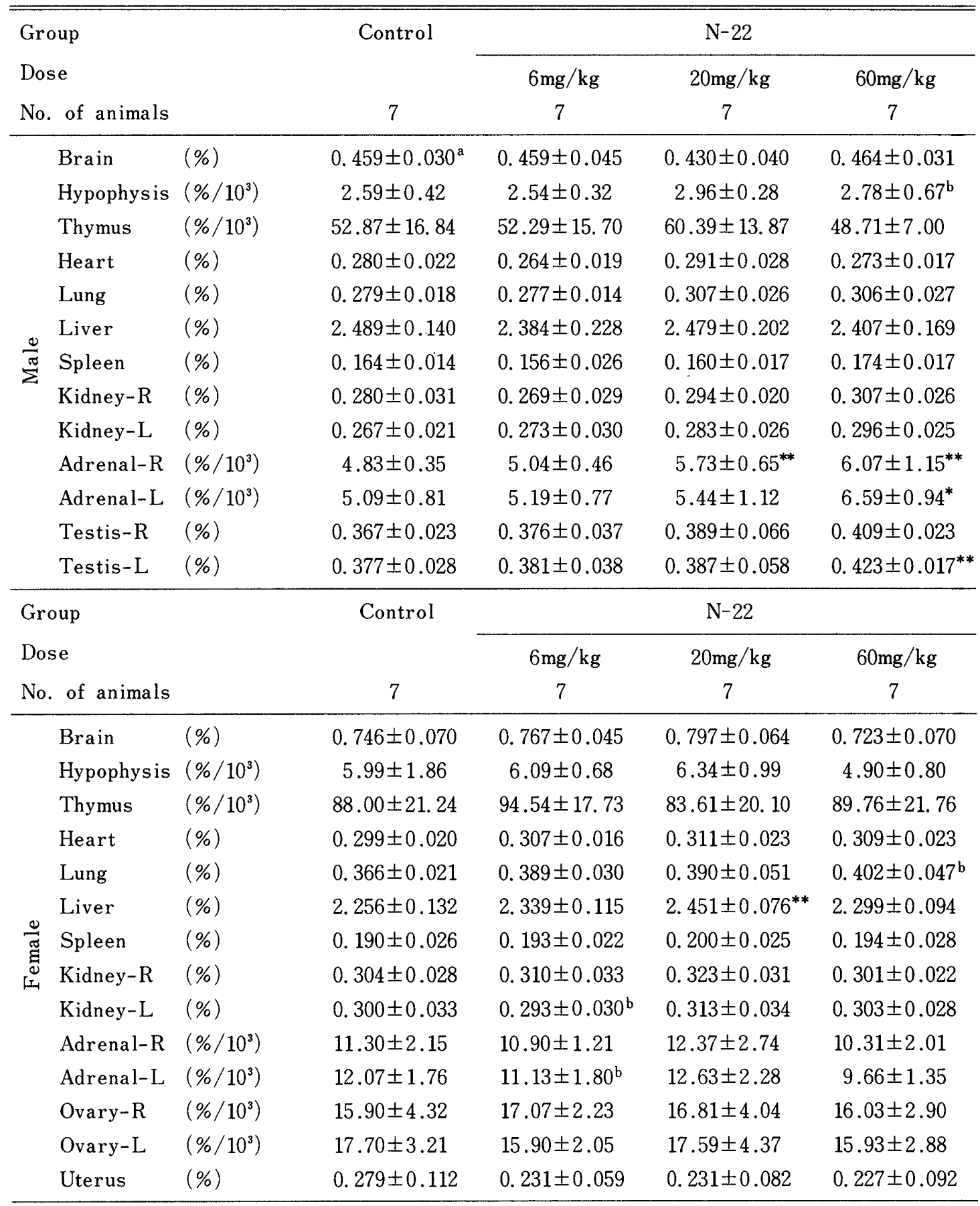

a: Values are means \pm S. D.

$\mathrm{b}$ : Six animals were examined.

* : Differs from control $(\mathrm{P}<0.05)$

** : Differs from control $(\mathrm{P}<0.01)$ 
K. SHIMPO et al.

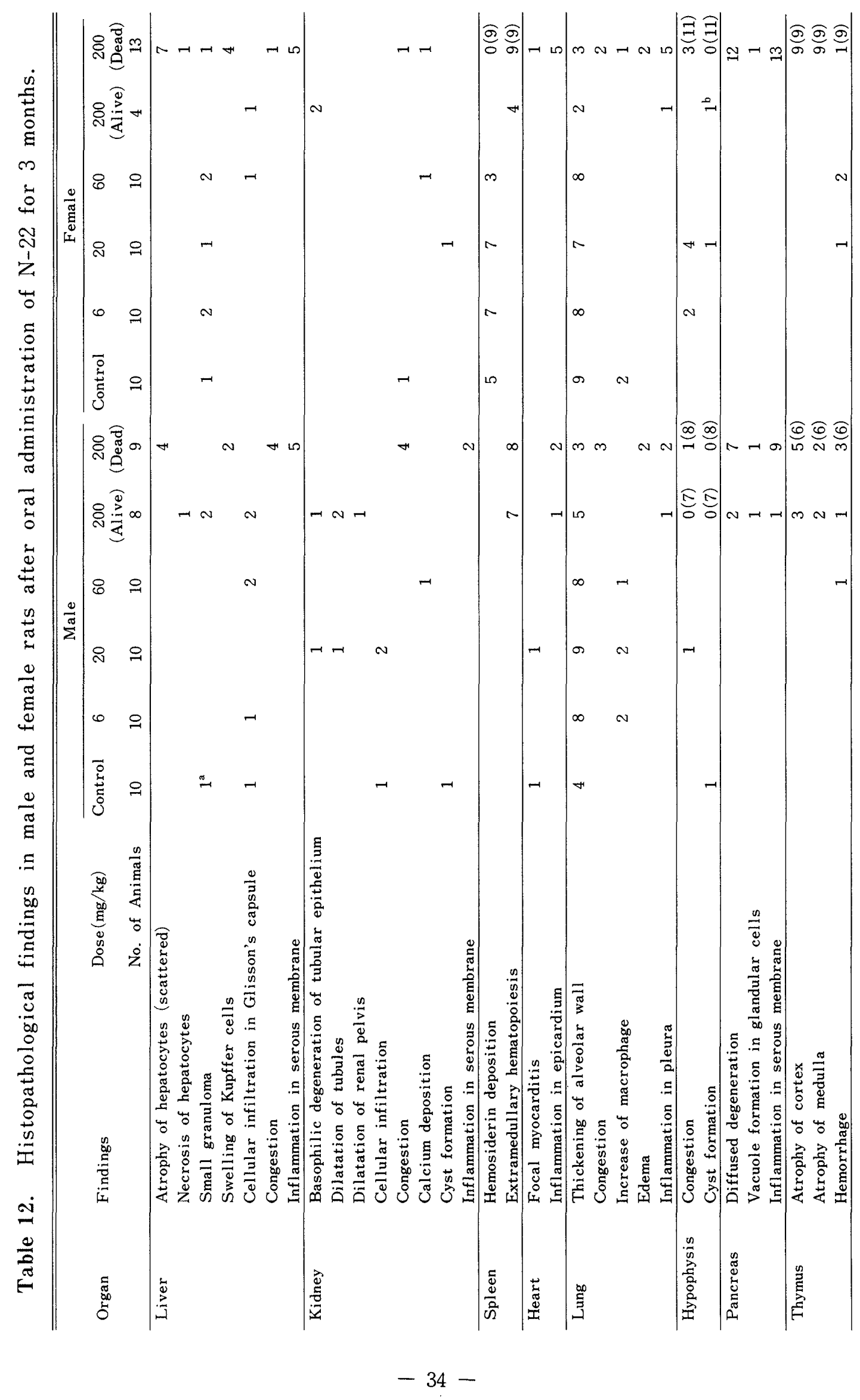


Subacute toxicity study of mofezolac $(\mathrm{N}-22)$ in rats

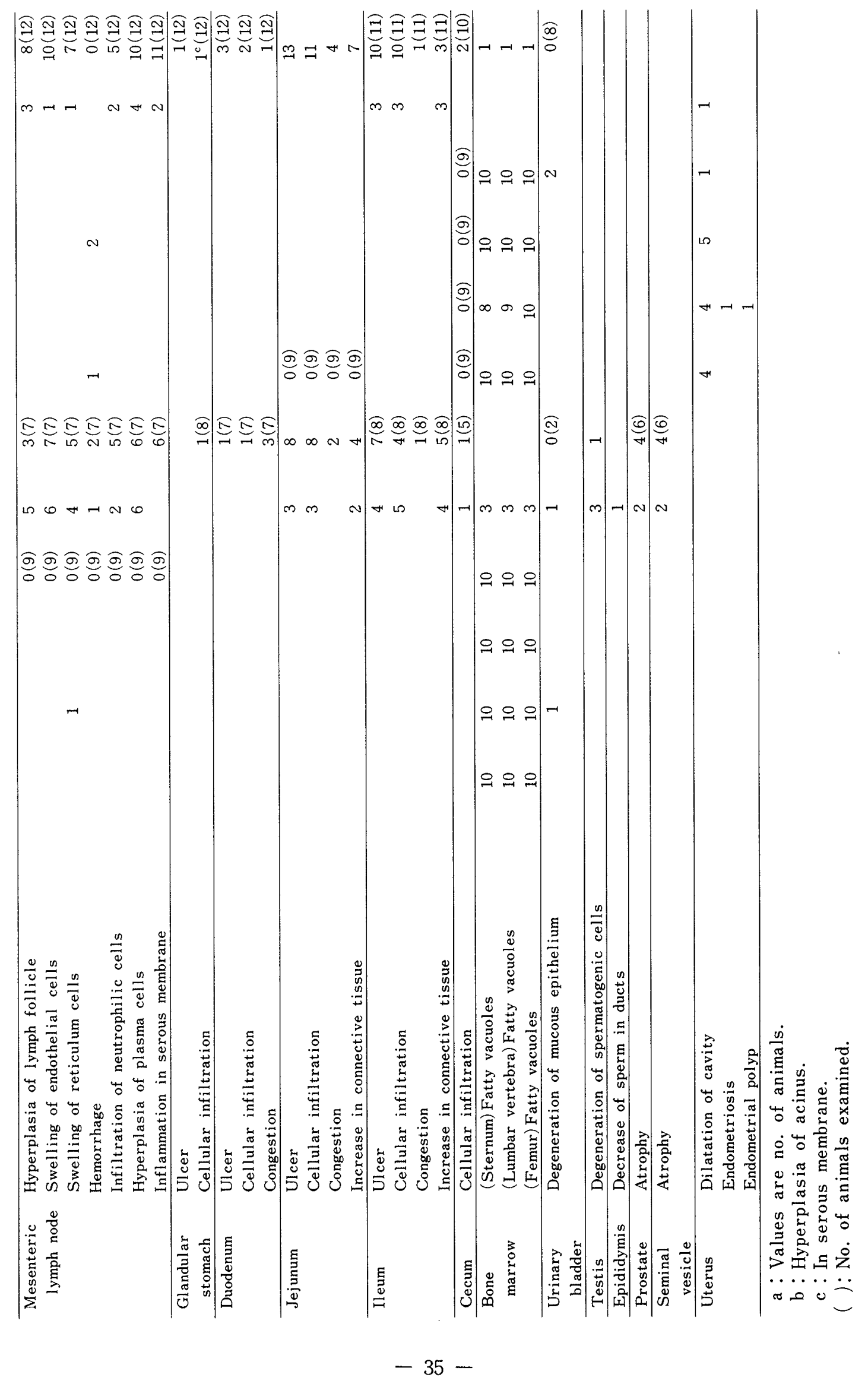


K. SHIMPO et al.

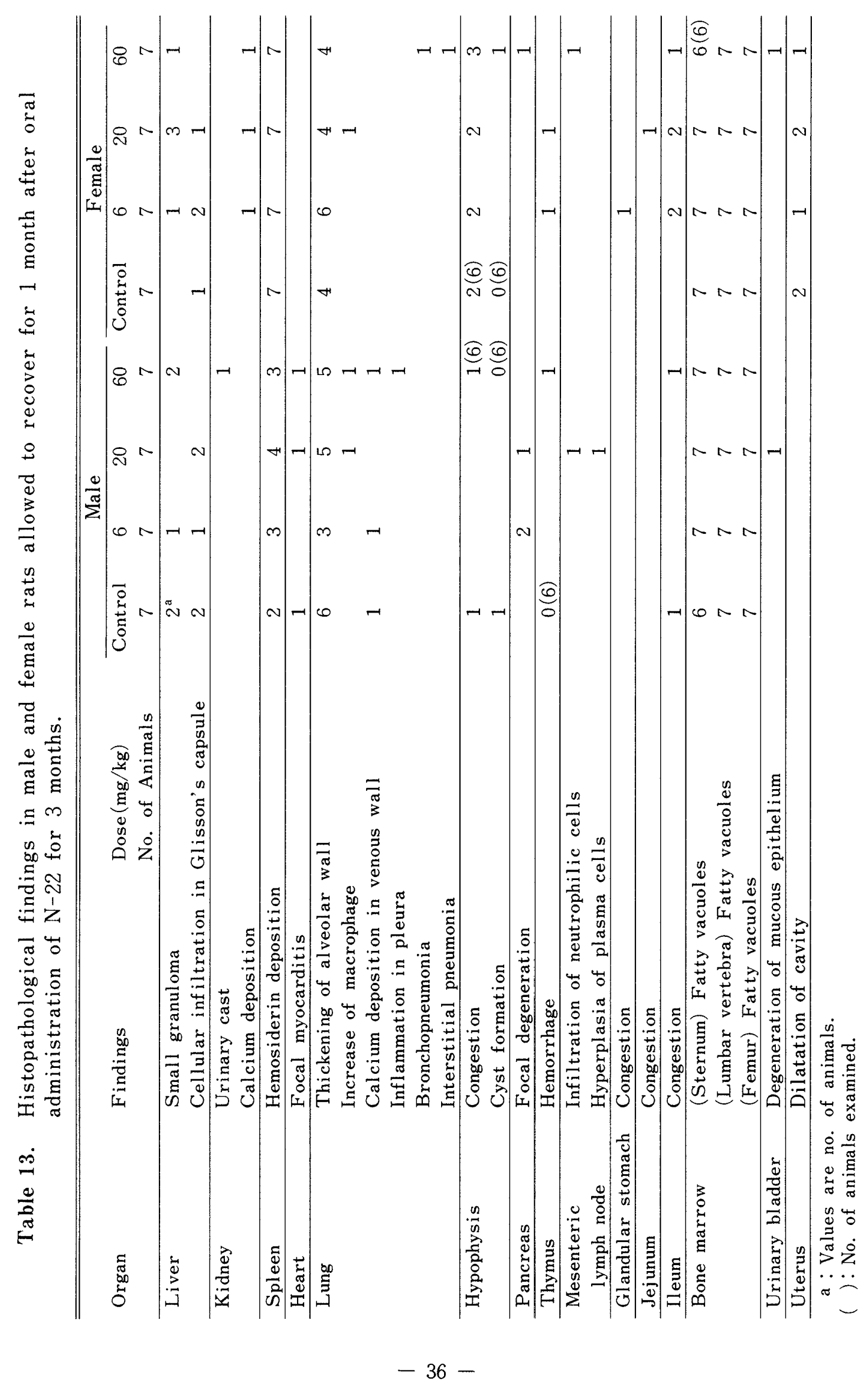


Subacute toxicity study of mofezolac $(\mathrm{N}-22)$ in rats

1 ) 死亡動物

死亡例では雌雄に共通して空腸および回腸の潰瘍（Photo 1), うつ血および細胞浸潤, 胸腺の萎縮, 肺のうっ血, 水腫および肺胞壁肥厚, 膵の被膜炎あるいはびまん性の腺細胞 変性, 脾の髄外造血亢進, 肝の肝細胞萎縮および被膜炎, 腸間膜リンパ節の洞内皮および 細網細胞の腫大あるいは形質細胞の增加を伴ったリンパ濾胞の過形成および被膜炎なゼを 認めたほか，雄では精囊あるいは前立腺の萎縮がみられた。

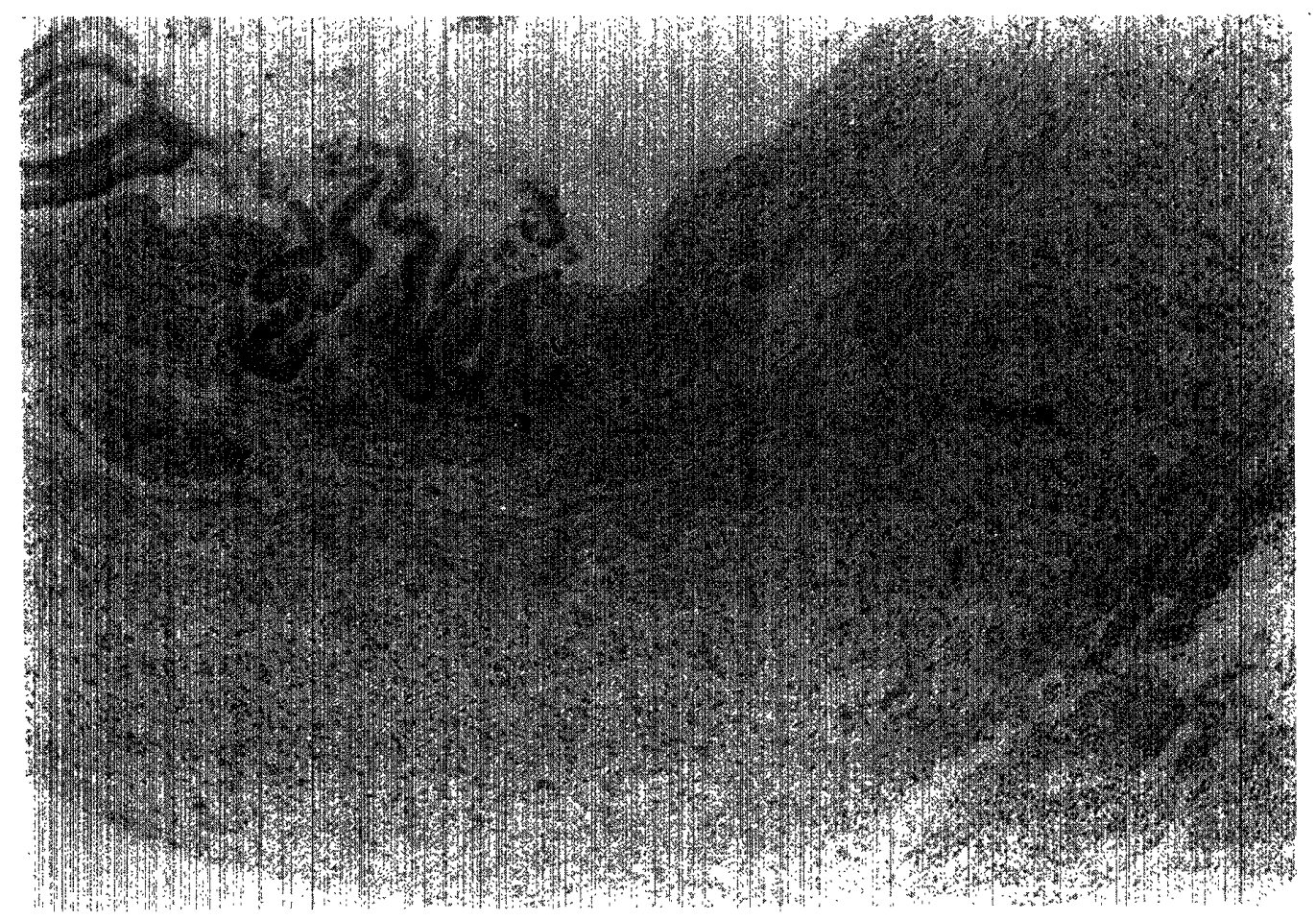

Photo. 1. Jejunum of a male rat demonstrating ulceration, cellular infiltration, congestion and increase in connective tissue. The rat was treated orally with $200 \mathrm{mg} / \mathrm{kg}$ of $\mathrm{N}-22$ for 13 weeks. H. E. staining, $\times 20$.

\section{2) 13 週解剖群}

$200 \mathrm{mg} / \mathrm{kg}$ 群の雌雄の少数例に上記死亡動物にみられた空腸, 回腸（Photo 2,3）, 胸腺, 肺, 膵, 脾, 腸間膜リンパ節なゼの変化が軽度にみられた。そのほか対照群を含む雄また は雌の各群に肺胞壁の肥厚, 骨髄の脂肪空胞増加, 肝の小結節, 脾のヘモジデリン沈着, 子宮内腔の拡張なざがみられた。

\section{3 ) 回復群}

対照群を含む雄あるいは雌の各群に肺胞壁の肥厚, 脾のへモジデリン沈着, 骨髄の脂肪 空胞，下垂体のうっ血，子宮内腔の拡張などがみられた。 


\section{K. SHIMPO et al.}

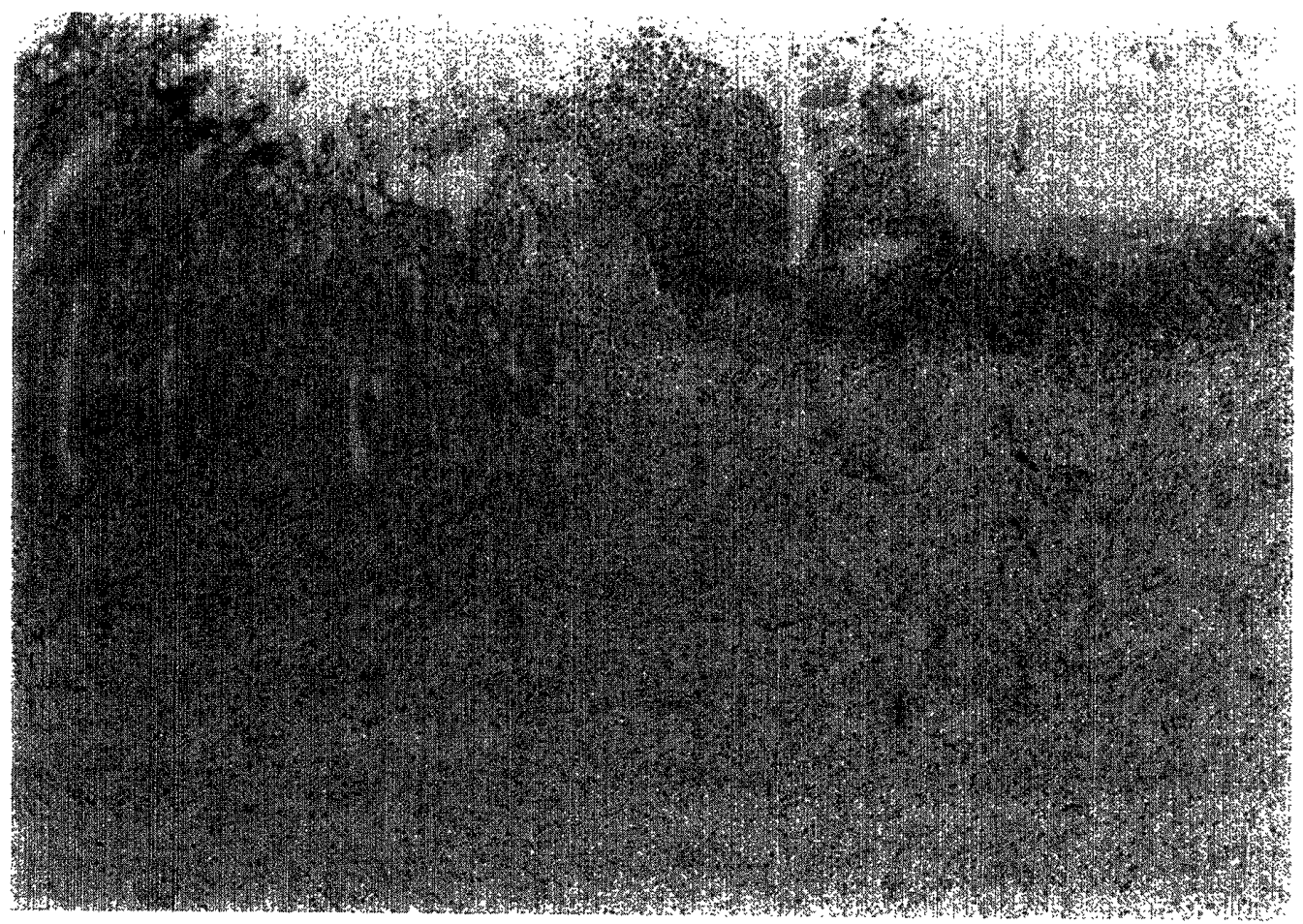

Photo. 2. Ileum of a male rat demonstrating ulceration, cellular infiltration, congestion and increase in connective tissue. The rat was treated orally with 200 $\mathrm{mg} / \mathrm{kg}$ of $\mathrm{N}-22$ for 13 weeks. H. E. staining, $\times 20$.

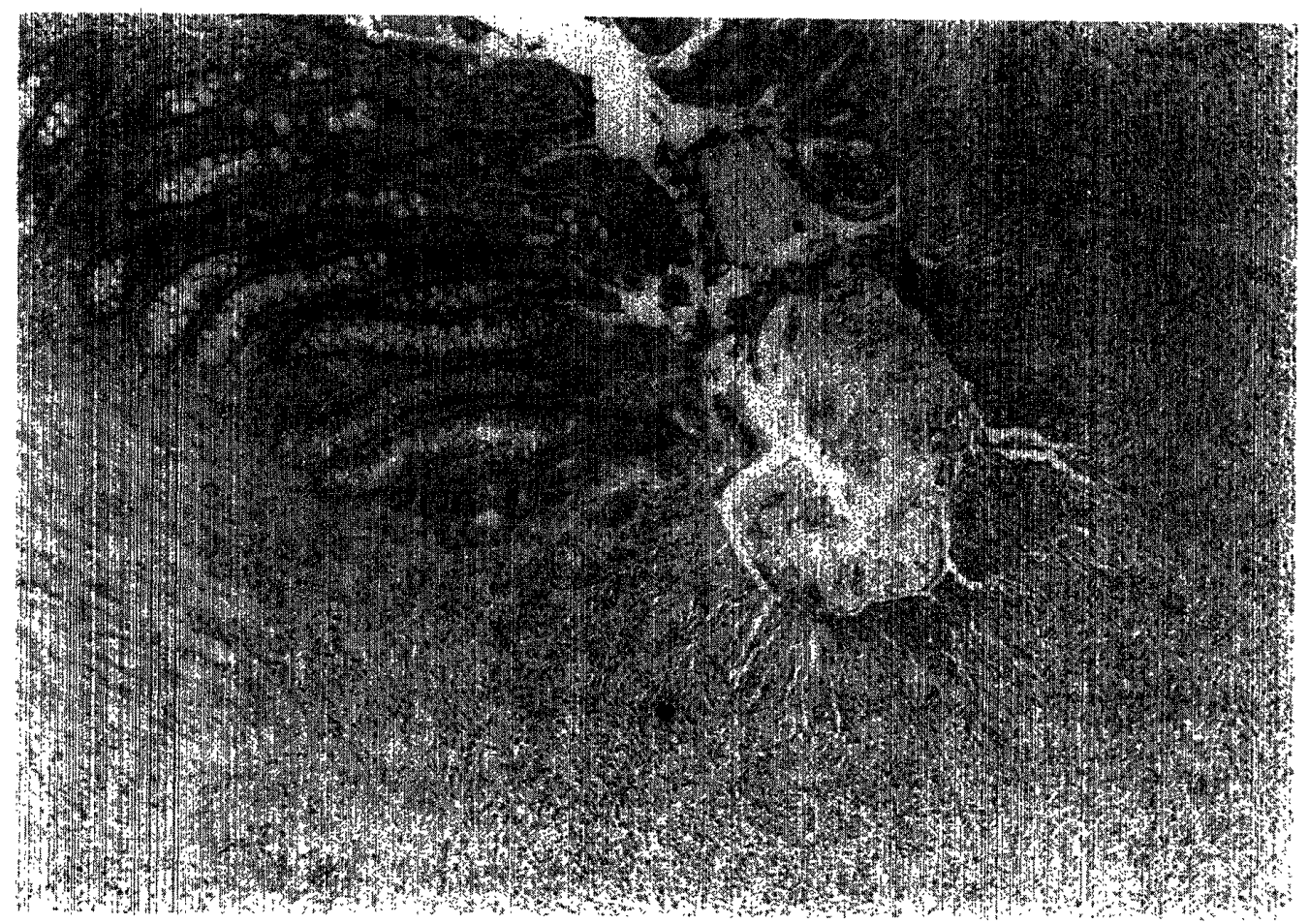

Photo. 3. Ileum of a female rat demonstrating ulceration, cellular infiltration, and increase in connective tissue. The rat was treated orally with $200 \mathrm{mg} / \mathrm{kg}$ of $\mathrm{N}-22$ for 13 weeks. H. E. staining, $\times 20$. 


\section{総括および考察}

ラットに $\mathrm{N}-22$ の $200,60,20$ および $6 \mathrm{mg} / \mathrm{kg}$ を 3 カ月間連続経口投与し，その亜急性毒 性および回復性を検討した。

一般状態の観察では最高用量群の $200 \mathrm{mg} / \mathrm{kg}$ 群で雌雄とも投与 3 週頃よりロ・鼻周囲の污 染, 立毛, 貧血, 下痢, 削瘦, 自発運動の減少などを示すようになり, 雄は投与 4 週頃より, 雌は投与 6 週頃より摄餌量の減少および体重の増加抑制が，さらに雄では投与 7 週頃より 摂水量の増加がみられ始めた。上記諸症状を呈した例のうち雄 9 例, 雌13例が投与 4 - 13 週に死亡した。死亡例では死亡前に血液を混じた下㢉の排泄がみられ, 病理学的に空腸お よび回腸では穿孔性潰瘍とそれに付随した混濁腹水, 腹腔内諸藏器の癒着のほか, 胸水の 貯留, 胸腔内臓器の㽷着など胸膜炎がみられ, さらに胸腺の萎縮, 肺のうっ血・水腫, 脾 の䯣外造血穴進などが確認された。これらの結果から, その死因は消化管障害に付随した 一般状態の悪化による衰弱死が推察された。非ステロイド系抗炎症薬はその投与により消 化管潰瘍を誘発することは既に多数報告されている（Brodie et al., 1970 ; Shriver et al., 1975 ; Cioli et al., 1979; Diamantis et al., 1980)。本試験で確認されたほとんどの例の消化 管潰瘍は空腸および回腸に発生しており，先に実施した急性毒性試験結果 (Satoh et al., 1990）と同様, 本剤のラットにおける潰瘍性病変の好発部位は小腸, 特に空腸および回腸 であることが示された。

尿検査では $20 \mathrm{mg} / \mathrm{kg}$ 以上の群の雄に $\mathrm{pH}$ の低下と $60 \mathrm{mg} / \mathrm{kg}$ 以上の群の雄にウロビリノーゲ ンの陽性化がみられた。また, 血液生化学的検査では $20 \mathrm{mg} / \mathrm{kg}$ 以上の群の雄に $\mathrm{Cl}^{-}$の減少が, $60 \mathrm{mg} / \mathrm{kg}$ 以上の群の雄にC $\mathrm{Ca}^{++}$の減少が, さらに $200 \mathrm{mg} / \mathrm{kg}$ 群にChE, TPおよびAlbの減少, BUN, UA, K+ ${ }^{+}$増加などのほかGOT, LDH活性の上昇がみられた。一般に非ステロイド 系抗炎症薬では消化管障害のほかに肝および腎障害が知られており（本間，1980; 入交， 1982），上記検査値は本剤の肝あるいは腎への影響を示唆する所見と考えられた。しかし ながら, 肝および腎では臟器重量あるいは相対重量の軽度増加がみられたのみであり, 病 理学的検査において肝あるいは腎障害を示唆する変化は認められていない。従って, 上記 検査値の変動は消化管の潰瘍性病変による一般状態の悪化あるいは衰弱に基づく変化と推 察された。また, 血液学的検査では $200 \mathrm{mg} / \mathrm{kg}$ 群で赤血球系の減少と網状赤血球率あるいは 好中球率の増加がみられ, 病理学的にも髄外造血の亢進を伴った脾腫なざが観察されたほ か, 諸蔵器の裉色, 腸間膜リンパ節の濾胞の過形成および形質細胞の増生を伴う腫大, 腹 腔内諸臓器の被膜の炎症性変化がみられるなど, 消化管潰瘍による失血および強度の炎症 反応により上記血液学的変化が招来されたものと推察された。

そのほか $200 \mathrm{mg} / \mathrm{kg}$ 群では脾, 副腎の重量ないし相対重量の増加, 雄の精䨢および前立腺 の萎縮なども認められたが，いずれも本剤投与による直接的な障害というよりはむしろ二 次的な要因によるものと推察された。

以上のように，N-22の 3 力月間の経口投与により観察された主な毒性所見は消化管障害 


\section{K. SHIMPO et al.}

であり, 同変化は雔雄とも $200 \mathrm{mg} / \mathrm{kg}$ 群では明らかであった。しかし, 上記諸変化は 1 力月 間の休薬によりいずれも回復ないし回復傾向がみられ，可逆的な変化であることが示され た。

以上の結果加ら，N-22のラットを用いた 3 力月間覀急性毒性試験における無影響量は雄 が $6 \mathrm{mg} / \mathrm{kg}$, 雌が $60 \mathrm{mg} / \mathrm{kg}$ ，また，確実中毒量は雌雄とも $200 \mathrm{mg} / \mathrm{kg}$ と推定された。

\section{要約}

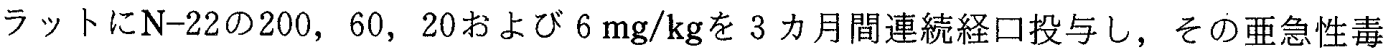
性および回復性について検討を行い, 以下の知見を得た。

1. 一般状態の観察では $200 \mathrm{mg} / \mathrm{kg}$ 群に口・鼻周囲の污染, 立毛, 貧血, 下㢉, 削瘦, 自発 運動の減少などがみられた。死亡は $200 \mathrm{mg} / \mathrm{kg}$ 群の雄 9 例，雌 13 例で投与 $4 \sim 13$ 週にみられ， 血液を混じた下痢の排泄を呈し衰弱死した。

2. 摂慨量の減少および体重の増加抑制が $200 \mathrm{mg} / \mathrm{kg}$ 群の雄では投与 4 週頃, 雌では投与 6 週頃より，さらに摂水量の増加が $200 \mathrm{mg} / \mathrm{kg}$ 群の雄で投与 7 週頃よりみられた。

3 . 尿検査では $20 \mathrm{mg} / \mathrm{kg}$ 以上の群の雄に $\mathrm{pH}$ の低下が, $60 \mathrm{mg} / \mathrm{kg}$ 以上の群の雄にウロビリノ一 ゲンの陽性化がみられた。

4. 血液学的検査では $200 \mathrm{mg} / \mathrm{kg}$ 群の雌雄に $\mathrm{RBC}, \mathrm{Ht}$ 值, $\mathrm{Hb}$ 量の減少と網状赤血球率の増 加が，雄に好中球率の増加がみられた。

5. 血液生化学的検査では $20 \mathrm{mg} / \mathrm{kg}$ 以上の群の雄に $\mathrm{Cl}^{-}$の減少が, $60 \mathrm{mg} / \mathrm{kg}$ 以上の群の雄に $\mathrm{Ca}^{++}$の減少が, また, $200 \mathrm{mg} / \mathrm{kg}$ 群の雙雄にChE, TP, Albの減少, BUN, UA, $\mathrm{K}^{+}$の増加, 雌にGOT，LDH活性の上昇がみられた。

6 . 臟器重量では $200 \mathrm{mg} / \mathrm{kg}$ 群に肝, 腎, 脾, 副腎の重量あるいは相対重量の軽度増加がみ られた。

7. 病理学的検査では $200 \mathrm{mg} / \mathrm{kg}$ 群の死亡例に空腸および回腸の穿孔性潰瘍とそれに付随し た混濁腹水, 腹腔内諸臓器の瘾着之被膜の炎症性変化, 脾腫, 腸間膜りンパ節の腫大, さ らに胸腔内臓器の炎症性変化なゼがみられた。 $200 \mathrm{mg} / \mathrm{kg}$ 群の生存例では少数例ないし約半 数例に死亡例と同様の諸変化が軽度に認められた。

8.上記諸変化は 1 カ月間の休薬によりいずれも回復ないし回復傾向を示し, 可逆性の変 化であった。

9.本試験における無影響量は雄が $6 \mathrm{mg} / \mathrm{kg}$, 雌が $60 \mathrm{mg} / \mathrm{kg}$, 確実中毒量は雌雄とも $200 \mathrm{mg} / \mathrm{kg}$ と推定された。

\section{文献}

Brodie, D. A., Cook, P. G., Bauer, B. J., et al. (1970) : Indomethacin-induced intestinal lesions in the rat. Toxicol. Appl. Pharmacol., 17, 615-624.

Cioli, V., Putzolu, S., Rossi, V., et al. (1979) : The role of direct tissue contact in the production 
Subacute toxicity study of mofezolac $(\mathrm{N}-22)$ in rats

of gastrointestinal ulcers by anti-inflammatory drugs in rats. Toxicol. Appl. Pharmacol., 50, $283-289$.

Diamantis, W., Melton, J., Sofia, R. D., et al. (1980) : Comparative gastric ulcerogenic effects of meseclazone, 5-chlorosalicylic acid and other nonsteroidal antiinflammatory drugs following acute and repeated oral administration to rats. Toxicol. Appl. Pharmacol., 52, 454-461.

本間 光夫 (1980)：抗炎症剤の副作用発現傾向について. 医薬品研究，11，529-541.

入交昭一郎 (1982) : 非ステロイド剤の種類と特徴. “炎症と抗炎症療法”水島 裕, 塩川優一 編集, p. 305-313. 医蒾薬出版, 東京.

Satoh, K., Yamamoto, N., Kuwasaki, E., et al. (1990) : Acute toxicity tests of mofezolac (N-22) in mice and rats. J. Toxicol. Sci., 15, Suppl. II, $1-9$.

Shriver, D. A., White, C. B., Sandor, A., et al. (1975) : A profile of the rat gastrointestinal toxicity of drugs used to treat inflammatory diseases. Toxicol. Appl. Pharmacol., 32, 73835. 